\title{
SyIthSOLIAR
}

LIBRARIES 




\section{THE FOUR CONTINENTS}

FROM THE COLLECTION OF JAMES HAZEN HYDE

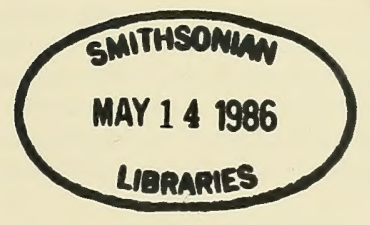

The Cooper Union Museum

Cooper Square, New York 3 
The works of art described in the following pages are delightful in themselves, and in pursuing their theme-worldly in the best sense! - they also give pleasant testimony to the high achievement of the designers and craftsmen of earlier periods. While in their excellence these objects speak most eloquently, their welcome presence in the Cooper Union Museum permits the Museum to record its gratitude for the great generosity with which the late James Hazen Hyde selected them from his entire collection, as being those that he considered most useful and desirable for the strengthening of the collections of the Museum. Such interest in knowing the most urgent needs of the Museum, and generosity in helping to supply them, were characteristic of this friendly benefactor during the many years of his informed and intelligent support of the Museum's undertakings.

The Cooper Union Museum, in publishing the present catalogue, is happy also to enjoy the collaboration of Professor Louis Réau, Membre de l'Institut, whose long friendship with Mr. Hyde gives particular value to the paragraphs that he has been so kind as to write for the Museum.

CALVIN S. HATHAWAY 


\title{
JAMES HAZEN HYDE
}

\author{
et son rôle d'ambassadeur culturel
}

entre les Etats-Unis et la France

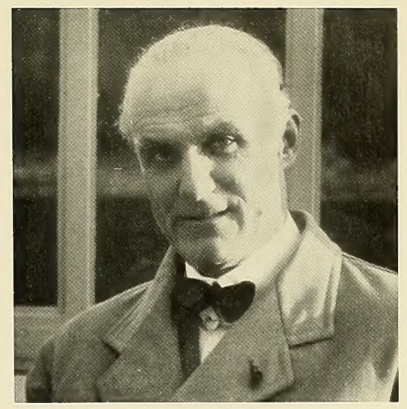

L'annonce de la mort de James Hazen Hyde, survenue le 28 juillet 1959 à Saratoga Springs, a été ressentie en France, où il a vécu de longues années jusqu’ à la seconde Guerre mondiale et où il comptait beaucoup d'amis, comme une perte infiniment regrettable au point de vue des relations intellectuelles et artistiques entre la France et les Etats-Unis.

Il était devenu en effet, officieusement sinon officiellement, un trait d'union entre son pays d'origine et sa patrie adoptive, soit en développant les échanges de professeurs entre les Universités des deux pays que l'Océan Atlantique unit autant qu'il les sépare, soit en exerçant la présidence de la Fédération de l'Alliance Française aux Etats-Unis et au Canada.

Les mérites de cet Américain, ami sincère et fidèle de la France dans les années de guerre et de détresse comme dans l'euphorie de la paix retrouvée, avaient été reconnus en 1938 par l'une des sections de l'Institut de France, l'Académie des Sciences Morales et Politiques, qui l'avait élu membre associé.

Dans sa résidence parisienne de la rue Adolphe Yvon à Passy aussi bien que dans sa magnifique propriété de Versailles, où ses jardins, tracés dans le goût de Lenôtre, rivalisaient avec ceux du Roi-Soleil, il se plaisait à recevoir une élite intellectuelle de savants, d'écrivains et d'artistes qu' il mettait en rapport avec ses compatriotes de passage à Paris. Beaucoup d'idées fécondes ont été échangées dans ces réceptions, intimes ou fastueuses, qui ont contribué très efficacement à créer une atmosphère de compréhension mutuelle.

En quittant la France pour regagner New-York, il tint à lui laisser un gage de son affection et un cadeau d'adieu en donnant au Musée des Arts Décoratifs la magnifique bibliothèque de livres d'Art qu'il avait constituée: libéralité d'autant plus précieuse que le fonds des ouvrages en langues étrangères, particulièrement en anglais et en allemand, était relativement pauvre.

Sa collection d'oeuvres d'art ne présentait pas un moindre intérêt que sa bibliothèque; il s'était spécialisé dans l'étude d'un sujet qui le passionait: l'iconographie des quatre Parties du Monde. Il avait publié sous ce titre un excellent article, trés documenté et abondamment illustré, dans la Gazette des Beaux-Arts. Cet article était basé sur des recherches personnelles et tenait compte, pour la première fois, des ouvrages de toute nature: plafonds peints, tapisseries, tableaux et gravures où est traité ce thème décoratif devenu si populaire à partir de la découverte de l'Amérique par Christophe Colomb.

Le Moyen-âge ne connaissait que trois continents, symbolisés par les trois Rois Mages apportant leurs présents à l'Enfant Jésus: l'Europe, l'Asie et l'Afrique. Du jour oì les Parties du Monde furent en nombre pair, comme les Quatre Saisons, les décorateurs, qui sont toujours gênés par les nombres impairs, adoptèrent ce motif qui prêtait à des effets de pittoresque exotique.

Je suis particulièrement heureux que l'éminent Directeur du Musée d'Arts Décoratifs de la Cooper Union for the Advancement of Science and Art, Mr. Calvin S. Hathaway, avec lequel j'étais entré en relation à Paris grâce à James H. Hyde, m'ait offert l'occasion 
d'apporter mon hommage personnel à ce grand ami de la France, envers lequel j'avais à acquitter une dette de gratitude.

C'est à son amitié que je dois d'avoir fait à deux reprises des tournées de conférences aux Etats-Unis et au Canada, dans les Universités et les cercles de membres de l'Alliance Française. J'ai tenu pour cette raison à lui dédier le livre que j'ai publié en I926, au retour d'un de ces voyages, sur L'Art français aux Etats-Unis.

Il s'intéressait particulièrement au grand sculpteur Houdon, qui fit le premier en 1785 la traversée de l'Atlantique pour exécuter de visu, d'après nature, la statue en marbre du général Washington, commandée par l'Etat de Virginia pour le Capitole de Richmond.

Sachant que je préparais depuis longtemps une monographie de ce statuaire qui fut, comme lui, un trait d'union entre la France et l'Amérique, il eut la gentillesse de mettre à ma disposition toutes les fiches bibliographiques rassemblées sous sa direction par ses bibliothécaires et secrétaires.

Ces matériaux m'ont été fort utiles pour la rédaction du Catalogue critique des statues et des bustes de Houdon qui sera annexé à mon ouvrage en cours d'impression.

La générosité et le désintéressement dont fit preuve pendant sa longue vie James $\mathrm{H}$. Hyde, toutes les fois qu'il s'agissait de promouvoir et de renforcer, dans le domaine de l'Art et de la Science, la traditionnelle amitié franco-américaine, font le plus grand honneur à sa mémoire.

LOUIS RÉAU, Membre de l'Institut 


\title{
THE FOUR CONTINENTS:
}

\author{
An Allegory for Artists
}

In an era preoccupied with astrophysical exploration, the familiar subject of geographyliterally the description of the Earth's surface-may appear as cozily outmoded as a Model $\mathrm{T}$ in comparison with a jet. We are no longer awed by distances and discoveries on the face of the globe; nor can we be, in the presence of scientific speculations revolving around the possibilities of life on stars and planets that were no more than sparkles on our ancestors' solid blue firmament. The wonderment at faraway countries, reached only by daring adventurers or invincible conquerors, is no longer ours. Nor would tales of dogheaded peoples and mythical beasts like the unicorn find many listeners among the stayat-homes who now can tune in the latest reports of rockets and satellites. Our world is shrinking, as space concepts expand and become more familiar. Today's Sinbad is an astronaut, and our Candide may soon have to take his quest for education at least to a neighboring planet to present an illuminating satire on human society.

Still, this Earth is our heritage and our anchor. In mankind's immediate past - the three or four millennia of our Western civilization as it spread in ever-widening circles from the Mediterranean basin-history and geography were practically synonymous. Each political development, be it war, civil strife or population growth, brought new needs for expansion, new expeditions beyond familiar boundaries into terra incognita. The garden of the Hesperides with its golden apples was thought to lie beyond the Pillars of the World, to be reached only by demi-gods like Hercules. But soon both Phoenicians and Greeks of more ordinary parentage ventured past the big rock of Gibraltar and explored the shores of Britain and Ultima Thule.

The expanding, unfolding world, the excitement of new discoveries and new challenges and victories for the human spirit of enterprise were mirrored in sagas and epics, whether sung, written or carved in stone. The wonders of foreign lands, foreign peoples, strange customs and unfamiliar nature had to be recorded, and, where no words were used, they found their expression in symbols and allegories, soon understood by everybody. The dark captives marching in semi-frontal sameness across the walls of Pharaoh's tombchamber represented the subjugated countries to the south, rather than individual war prizes; on Greek friezes, Persians in Phrygian caps assumed the collective role of Barbarians; and Vercingetorix in Caesar's triumphal cortege enhanced his victory as a symbol of conquered Gaul.

Such personifications of geographic or ethnic units were related to those of ancient nature deities, like the river-gods on the pediments of the temple of Zeus in Olympia and of the Parthenon. In Hellenistic times, cities too were personified in the figure of a wallcrowned Tyche. When the sea, conquered, no longer separated the lands but rather provided a link between them, the idea of the continents emerged as a geographical concept. To the three-Asia, Africa and Europe - that bordered on the sea of the Ancient World, the fearless sailor-adventurers of the late fifteenth century added a fourth, America. Though representations of the first three occur in ancient art and during the 
Middle Ages, it was the addition of the fourth that truly endeared the subject to artists in all media. From the sixteenth century on, allegories of the Four Continents take their place beside those of the Four Seasons and the Four Elements in the imagery of the arts.

First, they displaced the Four Winds from the corners of the ornate compasses and maps. Next, the title pages of books on new geographical discoveries, published in great numbers, became their domain. In engravings illustrating religious and political tracts they brought their universal homage to God and King. The princely courts delighted in them at carousels and masques, where fantastic chariots and costumed attendants followed each other. On ceilings of churches and palaces from Tsarskoe Selo to Aranjuez and from Palermo to Stockholm, provincial artists and painters of international fame depicted them with as much grace and artistry as their knowledge allowed, most spectacularly perhaps Giambattista Tiepolo in the Würzburg Residenz and the Royal Palace in Madrid.

Augsburg goldsmiths worked relief medallions with the Four Continents into their masterpieces in silver-gilt, and Bohemian and Silesian glass engravers cut them into their fragile pokals. Fittingly, they were carved into exotic materials like rhinoceros horn and ostrich egg, and soon became the beloved subject of that new precious material of the eighteenth century, porcelain. Ridiculing the fashion of collecting it, Addison scathingly described a contemporary lady's library as containing "munkeys, mandarins and scaramouches, but few books." Such figurines of exotic nationalities-Turks, Chinese, Blackamoors-surely preceded the groups of the Four Continents in the production of the Meissen factory. But neither Kändler, the prodigious master modeler, nor Eberlein, nor Meyer, could resist the subject. In the I 753 inventory of the "Conditorey" of Count Brühl, director of the factory, two sets are mentioned under the heading of large figures; the price list of 1765 enumerates not fewer than six different groups in varying sizes, some of them of putti. Frederick the Great, during the occupation of the factory in the Seven Years' War, ordered both a large and a small set. Catherine of Russia wished to see herself represented as the dominant figure in an immensely complicated surtout-de-table, ordered from the Berlin factory, with numerous attendants and vassals.

Other porcelain factories followed the vogue for the Four Continents, with results varying from the elegance of a Ludwigsburg group to the awkward charm of one from Sweden's Marieberg. The artists used their own ideas, or those of other factories; they relied on circulating engravings, or, less often, on original drawings. Among the former a frequently used set was engraved after Martin de Vos; examples of the latter are Gottfried Bernhard Götz's drawings, which inspired two Meissen sets. Illustrations from travelogues were also used, without necessarily guaranteeing a more accurate representation of the attributes of the Continents.

Legends and tales told by far-flung voyagers depicted often more colorfully than reliably the wonders of distant countries. Fabulous wealth, fantastic animals, miraculous substances, the Fountain of Youth and the Stone of Wisdom all had their home in the vague domains beyond the perimeter of the known world; and anything coming from those countries was expected to be fantastic and unreal, even abstruse, just as Jean Cocteau as a child believed that foreigners did not really have a language but feigned it only, speaking a meaningless gibberish. The qualities of the surreal and absurd were so closely wedded to the concept of the foreign that they often persisted long after more realistic reports had established a fund of reliable intelligence about the new countries. Increasing contacts did result in better knowledge, but only reluctantly were the fascinating myths abandoned, as with the abominable snowman in our own mid-century. Rather, with the irrepressible human penchant for masquerade, the real and the fantastic were fused together to provide a half-realistic, half-symbolic clothing for the images of distant lands. Thus costumes and headdresses, attributes and paraphernalia are far more telling than facial lineaments in the characterization of the Continents.

Africa, with its dark-skinned peoples, its towering elephants and fierce lions, had early 
acquired its distinguishing attributes. A fountain in ancient Rome, a mosaic in Palestrina, among others, show female heads crowned by elephant heads, complete with trunk, tusks and ears. Through centuries Africa continued to be represented with this abstruse but unmistakable head-gear, and although Asia occasionally is accompanied by an elephant, she is never thus crowned. The lion figures most frequently as the symbolic animal of Africa, deriving, like the elephant, from Carthaginian, North-African lore; sometimes, however, the Nilotic concept dominates with a crocodile, perhaps as an echo of the many representations of Father Nile. The camel really belongs to Asia, but is given to Africa on occasions, and quite logically so. The scorpion too is used, and the snake, again a reference to Egypt, as is the sheaf of wheat, and, by derivation, a cornucopia. The elephant tusk or branches of coral, endowed with miraculous healing powers, are other attributes of Africa, and for the martial side, quiver, bow and arrows. Feather skirts and headdresses are rare in early representations, and may very well have entered the artistic vocabulary by some kind of faulty deductive reasoning brought about by the Western slave trade, equating the African with the equally lightly-clad and uninhibited American Indian. Palms and pyramids are often pictured in the background, and the rays of a full sun disk are intercepted by leafy parasols.

The image of barbaric Asia, as represented by the Greeks, was not as durable as the Roman personification of Africa. True to the all-encompassing spirit of the allegorical concept of the Four Continents, even the bloody memory of the crusades, the onslaught of the Saracens and the Turkish conquests were put aside in favor of a more peaceful image. Still, it was the Mohemmedan East that provided this image, China and other Far-Eastern countries being too distant and too little known in their self-sufficient seclusion to take on such a symbolic role; they achieved their own transposition into Western art in the chinoiseries of the seventeenth and eighteenth centuries.

The fabulous wealth of the Orient, already a myth in the ancient world through the treasures of Darius, became the leitmotiv in the representations of Asia. With flowing jewelled robes and turbans and richly bedecked camels or elephants, with censers to burn the sweet perfumes of Araby, the riches of countries along and beyond the caravan routes were evoked, as they had been in the Gospel of Saint Matthew: the Wise Men, coming from the East, presented to the Christ Child "gold, and frankincense, and myrrh."

The Magi, in a firmly-rooted Christian tradition, represent the three parts of the world, bringing tokens of their allegiance to the new-born King; in crêches as well as in Christmas plays, one of the Magi would wear a crown, the second a turban, and the third would have a black face-truly acting out the idea of the Three Continents, already suggested in the Old Testament by the three sons of Noah. In medieval illuminations and mosaics, the orb held by Christ is divided into three parts, inscribed with the names of the Continents, to suggest His reign "orbis et urbis." With the rise of Marian theology, the dogma of the Immaculate Conception was symbolized in the figure of the Virgin standing on a globe and treading on the snake, to redeem the world through her purity from original sin. Still later, the Virgin or sometimes the personified Church, was represented receiving the homage of the Four Continents in their allegorical guise.

Related to this representation is the image of Europe as it crystallized out of Christianity and humanism. In classical art, Europa was the princess from Asia Minor, abducted by Zeus in the guise of a bull and deposited on the northern shores of the Hellespont, subsequently named after her. Represented early in the 6th century в.C. on one of the metopes of the Sikyan treasury in Delphi, this mythological anecdote remained in favor, and is occasionally linked with the allegories of the Continents. However, the true personification of Europe in this context is the Queen; her regal pose differs markedly from that of the playful and not altogether unwilling victim of the classical kidnapping story. Crowned and ermined, holding orb and sceptre, she is the heiress to the Christian legacy, and its stronghold in the world. Her animal is the white horse of the princes, and her attributes trophies and symbols of the arts and sciences. 
If the attributes of Europe were easy to define because of familiarity and theological connotations, those of America were subject to more adventurous interpretations. As centuries of trade disclosed many aspects of Asia and Africa, and as their shores were visited with increasing frequency by European seafarers, the fantastic myths about them lost some of their credibility. With the discovery of the new Continent, many myths were transposed to the western hemisphere and, interpolated with the more than fabulous reports of the explorers and conquistadors, they grew to a somewhat heterogeneous complex.

The native dress was easy to render, consisting of feather skirt and headdress. Here the artist came closer to understanding the esteem in which feathers were held among the natives than did those whom the natives had sought to honor: Montezuma's most precious gift to Cortez was a feather headdress, so little valued by the gold-thirsty receiver that it soon was completely forgotten and lost from sight until its recent rediscovery in Vienna.

America is the hunter, or rather the huntress, with bow, arrow and quiver; occasionally such a gory trophy as a human head betrays the nature of some of the hunts. This points to a preponderance of elements associated with the South-American continent rather than the Northern in the representation of America, as was logical with the wholesale invasion of the former by conquistadors, adventurers and Jesuits, in contrast to the stray attempts at the colonization of the latter. The majority of the animals in the representation of America bear out this contention: armadillo, parrot, llama and monkey belong to the southern continent, where also flourish the alligator and the tortoise. Some of these animals were confused with those associated with Asia and Africa: the alligator may look like a crocodile, the llama like a camel, and even the sparsely used puma or jaguar can readily be taken for a lion. While the wild animals of Asia and Africa could be brought to Europe with, at worst, a short sea voyage, to be presented to sovereigns and exhibited to the curious, the long voyage from America made such transports from the West rather hazardous. The artist had to rely on more or less accurate descriptions, at least till the time came when he himself ventured out on his own exploration of the New World, to produce such spectacular accounts of its fauna and flora as the Surinaamsche Insecten by Maria Sibylla Merian, a result of her trip in 1699 .

After this, the addition of the fifth continent, Australia, was a definite anticlimax. The suspicion of its existence had hovered somewhere in the background of public acceptance for at least a century, but when finally put on the map by Captain Cook, it was practically ostracized by the artists. Whether through reluctance to give up the number of four that adapted itself easily to most decorating schemes, large or small, in favor of the rather unwieldy number of five; or out of despair at the attempts to endow this newcomer, dark as Africa, dangerous as America, with distinct characteristics of its own; or, finally, out of tact and finesse to ignore its existence rather than evoke its utilization as a prison colony, the antipodal land did not win entrance into the allegorical representation of the Continents until the later nineteenth century. Then, as Australia with boomerang and curly hair mass, or as Oceania with a long shield, riding a dolphin, it figures as a rather tame postscript to the glorious reign of the Four Continents in the arts.

Many concepts found their realization in these figures : human curiosity and daring, conquests, peaceful trade and thirst for riches, myths of eternal youth and of miraculous medicines, religious fervor, the festive spirit of masquerades, the romantic idea of the noble savage and the escapist myth of the lazy happiness of the Land of Cockaigne without toil or necessity. With only a few attempts at ethnic characterization, the allegorical figures of the Four Continents are embodiments of these concepts, rather than simple illustrations of geographical units. Dignified, almost regal in their attitudes, they are symbolic sovereigns treated without condescension as one another's equals in a truly peaceful realization of global coexistence on the easy terms of allegory.

HEDY BACKLIN 


\section{CATALOGUE}

\section{CERAMICS}

\section{Porcelain}

BLACKAMOOR. Dressed in diapered tunic and knee-length trousers, feather skirt and headdress, with quiver on back; seated cross-legged on cushion, holding flaming lamp in each hand. Porcelain, polychrome and gilt. Probably Austria, Vienna; I722-1730. Height $200 \mathrm{~mm}$. Accession Number 1960-I-70.

2 PLATE. Octagonal marli with cartouches of the Four Continents: Asia reclining, with parasol, camel, pyramid and pagoda; Europe as sailor, seated on cornucopia, with ship and cannon as attributes; Africa, nude, seated on rock, with elephant and crocodile; America with feather headdress, bow and arrow, and unidentifiable animal; between cartouches, four diapered ovals with urns; in centre, figure of Hope, with anchor, leaning against shield with the arms of William Ker (born I775), Jane Martin on escutcheon of pretence; surrounding it, husk garland and four anchors. Porcelain, polychrome and gilt. China, for the British market; I $795-1800$. Diameter $248 \mathrm{~mm}$. Acc. No. I960-I68.

3 ASIA. Female figure, holding censer and bouqet of tulips, seated on kneeling camel; rocky base. Porcelain, polychrome and gilt; model of 1783 by Carl Luplau (died I795). Denmark, Royal Copenhagen Porcelain Manufactory; late Igth century. Underglaze mark: waves, crowned. Height 3 I $3 \mathrm{~mm}$. Acc. No. I960-I-55A. Forming a set with 5 and 6.

4

EUROPA AND THE BULL. Female figure seated on flower-bedecked reclining bull; oval base with oak leaf molding. Porcelain, polychrome and gilt; model of 1783 by Carl Luplau after a Naples model attributed to Filippo Tagliolini (died I8I2). Late igth or early 20 th century. Underglaze mark: waves, crowned; overglaze: D v R 576 . Height $265 \mathrm{~mm}$. Acc. No. I960-I-56. Variant of a figure forming a set with 3,5 and 6 .

5 AFRICA. Female figure with elephant-head coif, holding cornucopia and snake, seated on tree stump and attended by reclining lion; rocky base. Porcelain, polychrome and gilt; model of $I 783$ by Carl Luplau. Late Igth century. Underglaze mark: waves, crowned; overglaze: D v R 577. Height $285 \mathrm{~mm}$. Acc. No. $1960-1-55 \mathrm{~B}$. Forming a set with 3 and 6 .

6 AMERICA. Female figure holding bow and arrow, seated on rock amidst aloe plants; attributes: alligator and severed human head; rocky base. Porcelain, polychrome and gilt; model of I 783 by Carl Luplau. Late I9th century. Underglaze mark : waves, crowned; overglaze: H.F. Height $273 \mathrm{~mm}$. Acc. No. 1960-I-55C. Forming a set with 3 and 5. I $960-1-57$.

AMERICA. Undecorated variant of 6. Underglaze mark: waves, crowned. Acc. No.

8 ASIA. Female figure, wearing loin cloth and holding fan, seated on jar. White porcelain; model by Arno Malinowski (1899- ). Denmark, Royal Copenhagen Porcelain Manufactory; 
about 1936. Underglaze mark: waves; overglaze: crown, Denmark; incised: 12486 BL-ch. Height $230 \mathrm{~mm}$. Acc. No. I960-I-50A. Forming a set with 9, 10,11 and 12 .

9 EUROPE. Female figure in swimming suit and cap, holding parasol, seated on pedestal. Underglaze mark: waves; overglaze: crown, Demmark; incised: 12485 . Height $236 \mathrm{~mm}$. Acc. No. 1960-1-59B. Forming a set with $8,10,11$ and 12 .

10 AFRICA. Female figure wearing grass skirt and circular necklet, holding shield, seated on drum. Underglaze mark: waves; overglaze: crown, Denmark; incised: 124870 . Height $233 \mathrm{~mm}$. Acc. No. $1960-1-59 \mathrm{C}$. Forming a set with $8,9,11$ and 12 .

it AMERICA. Female figure, wearing cape and head band with two feathers, seated on short totem pole. Underglaze mark: waves; overglaze: crown, Denmark; incised: 12489 . Height $245 \mathrm{~mm}$. Acc. No. I960-I-59D. Forming a set with 8, 9, 10 and 12 .

12 AUSTRALIA. Female figure, wearing grass apron, armlets and knee bands, and holding scallop shell, seated on palm stump. Underglaze mark: waves; incised: 12488 . Height $236 \mathrm{~mm}$. Acc. No. 1960-1-59E. Forming a set with 8,9, 10 and 11 .

13 EUROPE AND AMERICA as putti. Europe, wearing loin cloth, seated on scrolled pedestal, holding sceptre and orb; attribute: helmet; America, wearing feather apron and headdress, kneeling astride an alligator. Biscuit; after a Meissen model by Friedrich Elias Meyer (I 723-1785). France, probably Mennecy; last quarter of the I 8th century. Height $216 \mathrm{~mm}$. Acc. No. I960-I-64B. Forming a set with 1960-I-64A. Compare with Meissen model 36 and 38 .

14 ALLEGORY OF ASIA. Circular plaque painted with birds; cassowary, Chinese pheasant, Banda hoopoe, peacock and kingfisher. Porcelain, polychrome and gilt; painted by C. Freyssinges after a gouache by Edmé François Bouillat (1740-1810). France, Sèvres, 1927. Signed: C. Freyssinges d'après Bouillat. Diameter $160 \mathrm{~mm}$. Acc. No. 1960-I-63A. Forming a set with 15, 16 and 17.

15 ALLEGORY OF EUROPE. Circular plaque painted with birds; pheasant, cock, ducks, white heron and bustard. Signed: C. Freyssinges d'après Bouillat. Acc. No. 1960-1-63B. Forming a set with 14,16 and 17 .

16 ALLEGORY OF AFRICA. Circular plaque painted with birds; Guinea-hens, Numidian cranes, spoon-bill and Angola jay. Signed: C. Freyssinges d'après Bouillat. Acc. No. 1960-I-63C. Forming a set with 14,15 and 17 .

17 ALLEGORY OF AMERICA. Circular plaque painted with birds; cock-of-the-rock, little blue heron, red curlew, toucan, cockatoo, wild turkey (?) and macaw. Signed: C. Freyssinges d'après Bouillat. Acc. No. I960-I-63D. Forming a set with 14, 15 and 16.

18 ASIA. Standing female figure, wearing turban and holding pieces of cinnamon and an elephant tusk; attended by seated, turbaned putto, holding censer and horse-tail sceptre; square pedestal. Porcelain, polychrome and gilt; model by Wilhelm Christian Meyer (I726-I786). Germany, Berlin; I769-I770. Underglaze mark: sceptre. Height $350 \mathrm{~mm}$. Acc. No. 1960-I-44A. Forming a set with 19,20 and 21 .

19 EUROPE. Standing female figure, wearing ermine and crown, holding goose pen and sceptre; attended by putto, leaning on globe; attributes: book and sword; square pedestal. Underglaze mark: sceptre. Height $330 \mathrm{~mm}$. Acc. No. 1960-I-44B. Forming a set with 18,20 and 21.

20 AFRICA. Standing male figure, black, wearing tunic with feather belt and collar, and feather headdress, and holding bow; attended by monkey, holding quiver with arrows; square pedestal. Underglaze mark: sceptre. Height $322 \mathrm{~mm}$. Acc. No. I960-1-44C. Forming a set with 18, 19 and 21 . 


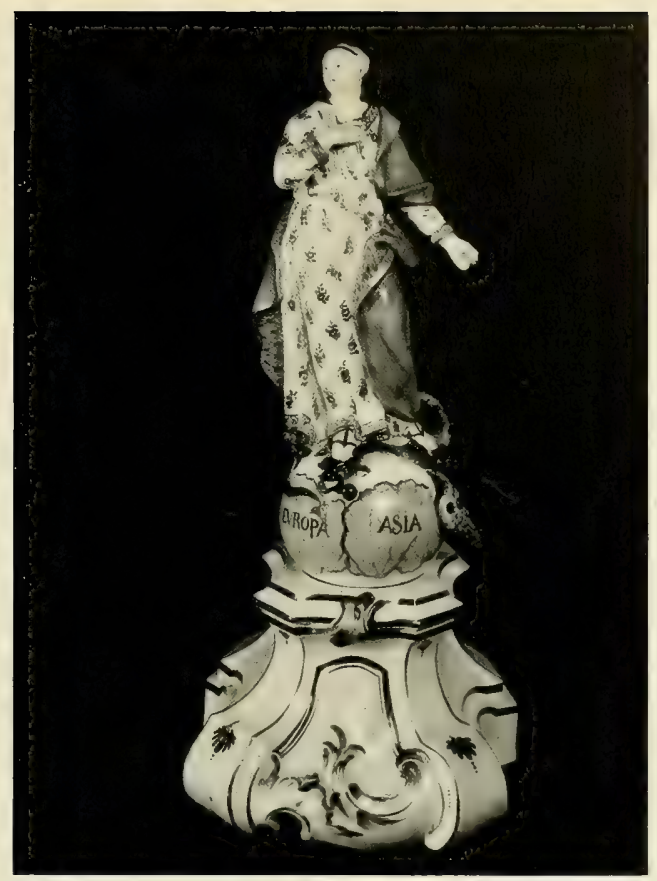

Catalogue Number 23

AMERICA. Standing male figure, wearing feather belt, long cape and headdress, holding sceptre and parrot; attributes: crocodile and cornucopia. Square pedestal. Underglaze mark: sceptre. Height $345 \mathrm{~mm}$. Acc. No. 1960-I-44D. Forming a set with 18,19 and 20.

ALLEGORY OF THE PEACE OF BASLE, I795. King Frederick William II of Prussia standing at left; Europe, seated and leaning on shield with relief of Europa and the Bull, receives the olive branch from the Angel of Peace standing behind her; in back, Justice, seated; inscription on circular socle: IUSTAM EUROPAE PACEM. Porcelain, polychrome and gilt; model by Schwarzkopf and Riese, after a sketch of the court sculptor Johann Gottfried Schadow (1764-1850). Germany, Berlin, 1795. Underglaze mark: sceptre. Height $308 \mathrm{~mm}$. Acc. No. 1960-I-45.

23 THE IMMACULATE VIRGIN, treading on a serpent, standing on the globe inscribed with the names of the Four Continents; scrolled pedestal. Porcelain, polychrome and gilt; model attributed to Wenzel Ney. Germany, Fulda; I770-1780. Underglaze mark: F F, crowned; incised: Ney (?). Height 3II mm. Acc. No. I960-I-42.(Illustrated)

24 TEA POT. Painted with allegorical scenes: for Africa, native digging up coral from the ground, another standing by with a lance, a third riding an elephant; palms and two lions in background; for America, two Indians, one standing, the other kneeling, wearing feather headdresses; alligator and three-master in background. Porcelain, polychrome and gilt; after drawings by Jacopo Amiconi(I675-I752). Germany, Höchst; about 1765. Underglaze mark: wheel, crowned; impressed: I M. Height roo mm. Acc. No. I960-I-46. 

America placed on four sides of pierced, scrolled pedestal with fruit finial in center. Porcelain, polychrome and gilt; model attributed to Johann Göz (1732-I762). Germany, Ludwigsburg; I760-I765. Underglaze mark: DC, crowned. Height $310 \mathrm{~mm}$. Acc. No. 1960-I-50. (Illustrated)

26 PEDESTAL FOR A FOUNTAIN: THE FOUR CONTINENTS. One kneeling and three standing atlantes, one of them black with feather skirt and headdress, grouped on three sides of pedestal on rocky base. Porcelain, with polychrome and gilt decoration probably added later; model by Johann Gottlob Kirchner (1706-1738?). Germany, Meissen; I 728-I 729. Underglaze mark: crossed swords. Height $304 \mathrm{~mm}$. Acc. No. I960-I-32.

27 AFRICA WITH SUGAR BASKET. Black figure, wearing feather skirt and headdress, standing beside flower-decorated basket with removable cover. Possibly representing AMERICA. Porcelain, polychrome; model by Johann Joachim Kändler (I 706-I 775). Germany, Meissen; about I730. Underglaze mark: crossed swords. Height I $70 \mathrm{~mm}$. Acc. No. I960-I-34.

28 ORIENTAL FRUIT VENDOR. Female figure, black, wearing long mantle and squared headdress, carrying basket of lemons. Porcelain, polychrome and gilt; model by Johann Joachim Kändler (I706-I 775). Germany, Meissen; I730-I740. Height I 39 mm. Acc. No. I960-I-39A.

29 AFRICA. Standing black figure, wearing feather skirt and headdress, an elephant skin over right arm. Porcelain, polychrome and gilt; model by Johann Joachim Kändler(I 706-1775). Germany, Meissen; about 1775 . Height I $59 \mathrm{~mm}$. Acc. No. I960-I-40.

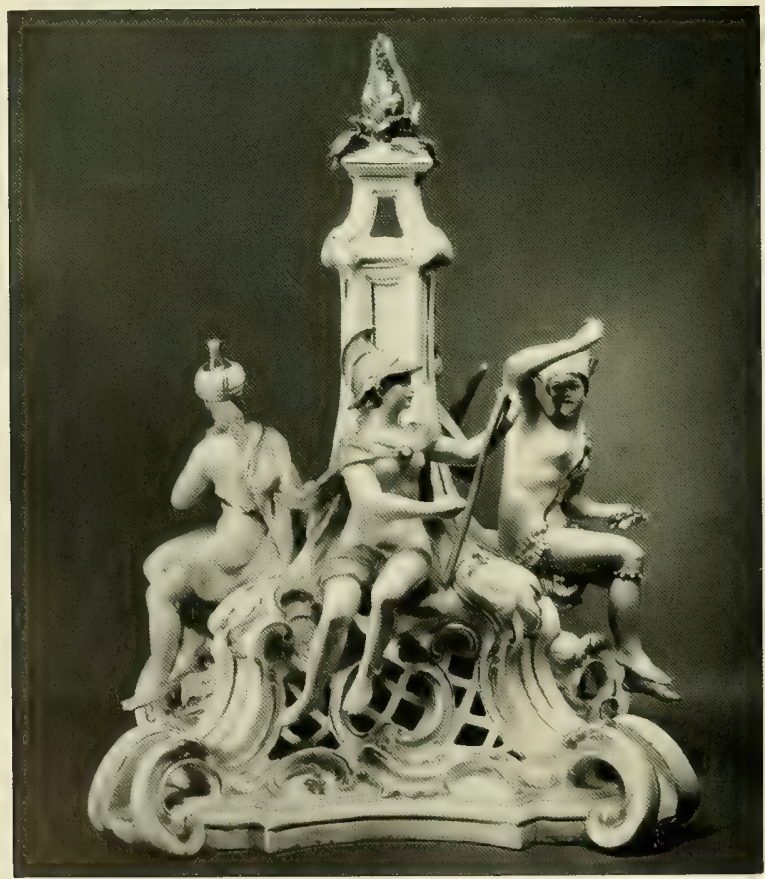

Catalogue Number 25 


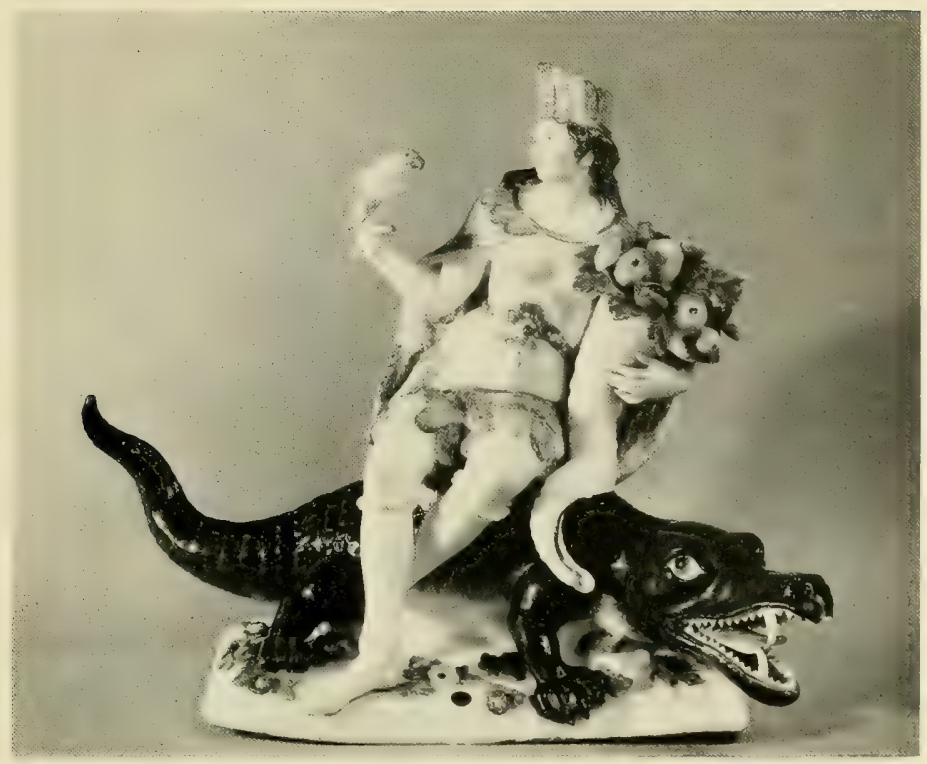

Catalogue Number 34

30

AFRICA. Standing female figure, black, wearing flowered skirt and cape and feather headdress, holding a stick. Porcelain, polychrome and gilk. Germany, Meissen; 1735-1745. Underglaze mark: crossed swords. Height $130 \mathrm{~mm}$. Acc. No. 1960-1-35.

31 ASIA. Turbaned female figure, holding sceptre and censer, seated on camel facing left; in background, a palm tree. Porcelain, polychrome and gilt; model by Johann Joachim Kändler ( I 706I775) and Johann Friedrich Eberlein (I696-I749), after a design by Gottfried Bernhard Götz (I 708 1774). Germany, Meissen; 1745-I 750. Underglaze mark: crossed swords. Height $300 \mathrm{~mm}$. Acc. No. I960-I-28 A. Forming a set with 32,33 and 34 . Larger variant of 45.

32 EUROPE. Crowned female figure, holding sceptre and orb, seated on piece of entablature beside a standing horse; attributes : books, globe, palette, shield and suit of armor. Model of 1746-1 750 by Kändler and Eberlein; about 1760 . Underglaze mark: crossed swords. Height $254 \mathrm{~mm}$. Acc. No. I960-I-28B. Forming a set with 31,33 and 34 .

33 AFRICA. Female figure, black, with elephant-head coif, feather tunic and leggings, holding sheaf of wheat; seated on crouching lion, facing left. Model by Kändler after a design by Gottfried Bernhard Götz, I746-I750. Height $303 \mathrm{~mm}$. Acc. No. I960-I-28c. Forming a set with 31, 32 and 34.

34 AMERICA. Female figure with feather skirt, mantle and headdress, holding parrot and cornucopia; seated on alligator facing right. Model by Eberlein and Peter Reinecke( I 7 I 5-I 768 ), after a design by Gottfried Bernhard Götz. Height $269 \mathrm{~mm}$. Acc. No. I960-I-28D. Forming a set with 31, 32 and 33. Larger, reversed variant of 48 . (Illustrated)

35 ASIA AND AFRICA as putti. Asia wearing loin cloth, seated on loin holding a sceptre; Africa, black, wearing a loin cloth and elephant coif, holding coral, seated on scrolled pedestal. Porce- 
lain, polychrome and gilt; model by Friedrich Elias Meyer (r723-1785). Germany, Meissen; about 1750. Underglaze mark: crossed swords. Height I3I mm. Acc. No. I960-I-36. Forming a set with 36. Smaller variant of 37. Copied in biscuit (1960-1-64A), and in faience 67.

36 EUROPE AND AMERICA as putti. Europe, wearing loin cloth, seated on scrolled pedestal, holding sceptre and orb; America, kneeling, facing Europe, wearing feather apron and headdress and holding a bow. Porcelain, polychrome and gilt; model of about 1750 by Friedrich Elias Meyer (1723-I 785). Germany, Meissen; about I 765 . Underglaze mark: crossed swords. Height 126 mm. Acc. No. I960-I-37. Forming a set with 35. Smaller variant of 38. Copied in biscuit 13 .

37 ASIA AND AFRICA as putti. Asia, wearing loin cloth, seated on scrolled pedestal, holding censer and half moon; Africa, black, wearing loin cloth and elephant-head coif, seated on lion and holding ribbon and branch of coral; attributes: quiver and arrows. Porcelain, polychrome and gilt; model by Friedrich Elias Meyer (1723-1785). Germany, Meissen; I750-1760. Underglaze mark: crossed swords. Height $235 \mathrm{~mm}$. Acc. No. 1960-I-4IA. Forming a set with 38. Larger variant of 35 . Copied in biscuit (1960-I-64A), and in faience 67 .

38 EUROPE AND AMERICA as putti. Europe, wearing loin cloth, seated on scrolled pedestal, holding sceptre and orb; attribute: helmet; America, wearing feather apron and headdress, kneeling astride alligator. Underglaze mark: crossed swords. Height 24I mm. Acc. No. I960-I-4IB. Forming a set with 37. Large variant of 36. Copied in biscuit 13.

39 EUROPA AND THE BULL. Female figure seated on bull; two attendants offering flowers from a basket. Porcelain, polychrome and gilt; model attributed to Friedrich Elias Meyer (1723I785). Germany, Meissen; I750-I 760. Underglaze mark: crossed swords. Height $220 \mathrm{~mm}$. Acc. No. I960-1-3I.

4o ASIA. Standing female figure, wearing jewelled mantle and turban with half-moon, holding sceptre and censer; attributes: relief cartouche with camel. Porcelain, polychrome and gilt; model by Friedrich Elias Meyer (1723-1785). Germany, Meissen; about I775. Underglaze mark: crossed swords. Height I $55 \mathrm{~mm}$. Acc. No. I960-I-29A. Forming a set with 41, 42 and 43.

41 EUROPE. Standing female figure, wearing ermine and crown, holding sceptre and orb; attributes: book, globe, cornice fragment, cornucopia and relief cartouche with horse. Height I 53 $\mathrm{mm}$. Acc. No. 1960-I-29B. Forming a set with 40,42 and 43 . Compare with 61 .

42 AFRICA. Standing black female figure, wearing feather skirt, mantle and elephant-head coif; holding sheaf of wheat; attributes: relief cartouche with lion. Underglaze mark: crossed swords. Height I $52 \mathrm{~mm}$. Acc. No. I960-I-29C. Forming a set with 40,41 and 43 . (Illustrated)

43 AMERICA. Standing female figure, wearing feather skirt, mantle and headdress; attributes: parrot perched on arm, quiver with arrows and relief cartouche with alligator. Height $150 \mathrm{~mm}$. Acc. No. 1960-I-29D. Forming a set with 40,41 and 42 .

44 BLACKAMOOR, carrying covered cup on tazza. Porcelain, polychrome and gilt; model of about I 740 by Johann Joachim Kändler (I706-I775), as part of a group with lady and cavalier. Germany, Meissen; late I 8 th century (?). Height I $40 \mathrm{~mm}$. Acc. No. 1960-I-39B.

45 ASIA. Turbaned female figure, holding sceptre and censer, seated on camel facing left; in background, a palm tree. Porcelain, polychrome and gilt; model of $\mathrm{I} 745$ by Peter Reinecke (I7I S1768), a variant of Kändler's and Eberlein's larger model after a design by Gottfried Bernhard Götz ( $1708-1774)$. Germany, Meissen; late I 8 th or possibly I 9 th century. Height $188 \mathrm{~mm}$. Acc. No. I960$\mathrm{I}-38 \mathrm{~A}$. Forming a set with 46,47 and 48 . Smaller variant of 31 .

46 EUROPE. Crowned and ermined female figure, holding sceptre and orb, seated on rearing horse facing right; attributes: globe and book. Model of 1745 by Peter Reinecke after a design by Gottfried Bernhard Götz. Height 2I 5 mm. Acc. No. I960-I-38B. Forming a set with 45,47 and 48. 


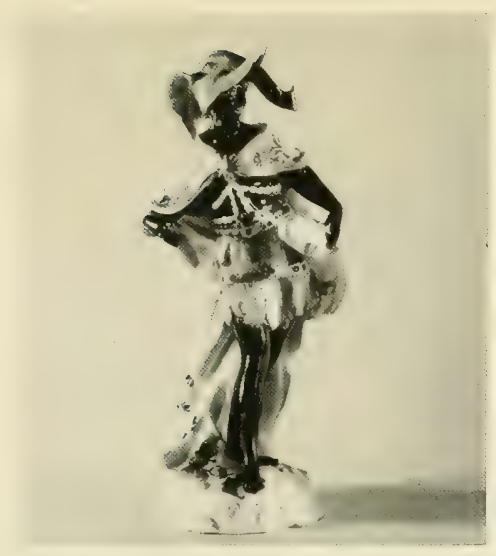

Catalogue Number 42

47 AFRICA. Female figure, black, with elephant-head coif, feather tunic and leggings, holding lemon and sheaf of wheat, seated on crouching lion facing right; in background, a tree. Model of I 745 by Peter Reinecke, after a design by Gottfried Bernhard Götz. Height I90 mm. Acc. No. 1960I- $38 \mathrm{C}$. Forming a set with 45,46 and 48 .

48 AMERICA. Female figure with feather skirt, mantle and headdress, holding cornucopia and partot, seated on alligator facing left. Model of 1745 by Peter Reinecke, a variant of his and Eberlein's larger model after a design by Gottfried Bernhard Götz. Height I $40 \mathrm{~mm}$. Acc. No. I960-I-38D. Forming a set with 45,46 and 47 . Smaller, reversed variant of 34 .

49 AMERICA. Slender female figure, wearing feather headdress and holding a reed flute; at her side, a small tree on which hangs a quiver with arrows. White porcelain. Germany, Nymphenburg; about 1930. Impressed mark: escutcheon, lozengy. Height 4 I 5 mm. Acc. No. I960-I-58.

5o EUROPE. Female figure, wearing ermine and imperial crown, holding sceptre, seated on horse, with draped tree in back; attended by putti, symbolic of war and peace. Porcelain, polychrome. Germany, probably Würzburg; about 1775. Height $357 \mathrm{~mm}$. Acc. No. I960-I-49.

51 DANCING INDIAN. Holding club in right hand and shicld in left, standing with one foot on starred globe; marble plinth. Porcelain, undecorated; model probably by Gaspare Bruschi. Italy, Doccia; about 1770. Height, without plinth, $307 \mathrm{~mm}$. Acc. No. I960-1-53.

52 ASIA. Female figure, with censer in left hand, seated on camel. Biscuit; model perhaps by Domenico Bosello (ca. I 755-I82I). Italy, probably Le Nove; late I 8 th century. Height $253 \mathrm{~mm}$. Acc. No. 1960-I-54A. Forming a set with 53,54 and 55 .

53 EUROPE. Female figure with imperial crown, holding model of a church in right hand, seated on cornucopia; attributes: rearing horse and cannon. Height $255 \mathrm{~mm}$. Acc. No. 1960-I-54B. Forming a set with 52, 54 and 55 .

54 AFRICA. Female figure with feather skirt and elephant coif, holding cornucopia, seated on lion. Height $274 \mathrm{~mm}$. Acc. No. I960-I-54C. Forming a set with 52, 53 and 55.

55 AMERICA. Female figure with feather headdress, seated on rock; attributes: alligator and severed human head. Height $262 \mathrm{~mm}$. Acc. No. 1960-1-54D. Forming a set with 52, 53 and 54 . 
AMERICA. Female figure, dressed in feather skirt, knee bands, epaulets and headdress, seated on alligator; right hand holding a ladle, left resting on back of a cockatoo; on back a quiver with arrows, and on the ground, a severed human head; marbled socle. Porcelain, polychrome and gilt. Spain, Alcora; about 1770 . Height $245 \mathrm{~mm}$. Acc. No. I960-I-52. Part of a set; compare with variant in Alcora faicnce, 71 .

57 ASIA. Standing female figure with flower wreath in hair, holding lamp and leaning against stone wall; attended by seated, bearded river god, camel and snake. Porcelain, polychrome and gilt. Spain, Buen Retiro; I9th Century. Height $391 \mathrm{~mm}$. Acc. No. 1960-1-51 A. Forming a set with 58,59 and 60 .

58 EUROPE. Standing female figure, crowned, holding sceptre and leaning against model of circular chapel; attended by bearded river god and horse. Height $443 \mathrm{~mm}$. Acc. No. I960-I-51B. Forming a set with 57,59 and 60 .

59 AFRICA. Standing female figure, black, wearing elephant head coif and holding scorpion and cornucopia; attended by bearded river god, lion and snakes. Height $38 \mathrm{~mm}$. Acc. No. I960-I5IC. Forming a set with 57,58 and 60 .

60 AMERICA. Standing female figure, wearing feather headdress; attended by bearded river god and alligator. Height $370 \mathrm{~mm}$. Acc. No. 1960-I-5ID. Forming a set with 57,58 and 59 .

61 EUROPE. Standing female figure, wearing ermine and crown, holding sceptre and orb; attributes: book, globe, comice fragment, cornucopia, and a horse in relief. Soft paste, polychrome and gilt; after a Meissen model by Friedrich Elias Meyer (I723-I785). Sweden, Marieberg; I7661769. Incised mark: MB H F. Height I $56 \mathrm{~mm}$. Acc. No. I960-I-60. Compare with 41.

\section{Stoneware}

62 AMERICA. Standing female figure, American flag in her right and laurel wreath in her left hand, wearing a diadem with star and leaning against a tree trunk, at the base of which an American shield with eagle, stars and stripes is placed. Black basalt stoneware; model probably by W. Beattie. England, Etruria, Josiah Wedgwood and Sons; I89I. Impressed mark: WedGwood ENGLAND I891. Height $348 \mathrm{~mm}$. Acc. No. I960-I $\rightarrow 62$.

\section{Earthenware}

63 AFRICA. Standing figure, wearing elephant-head coif; accompanied by lion. Unglazed earthenware. France or Italy, first half of the I8th century. Height $250 \mathrm{~mm}$. Acc. No. I960-I-90A. Originally from a set, including 64 .

64 AMERICA. Standing figure, wearing feather headdress and quiver and holding bow; accompanied by alligator. Height $253 \mathrm{~mm}$. Acc. No. I960-I-90B. Originally from a set, including 63.

65 AFRICA. Standing youth with elephant head coif, holding sheaf of wheat; attended by lion. Polychrome faience. France, probably Strasbourg; second half of the I 8 th century. Height I 50 mm. Acc. No. 1960-I-6IA. With 66, originally part of a set.

66 AMERICA. Bearded man, wearing animal skin and feather headdress, and holding a club; attended by turbaned child. Height I $50 \mathrm{~mm}$. Acc. No. I960-I-6IB. With 65, originally part of a set.

67 ASIA AND AFRICA as putti. Asia, holding flaming lamp and snake, back to back with Africa, black, wearing elephant-head coif, seated on lion. Polychrome faience; after a Meissen model by Friedrich Elias Meyer (I723-1785). France, probably Niderviller; last quarter of the I 8 th century. Height I77 mm. Acc. No. I960-I-67. Compare with Meissen models 35 and 37. 

with crescent moon, melon and censer. White faience. Spain, Alcora; last quarter of the 18 th century. Height $237 \mathrm{~mm}$. Acc. No. I960-I-69A. Forming a set with 69,70 and 71 .

69 EUROPE. Female figure, crowned, with sceptre in right hand, seated on reclining horse; attributes: imperial crown and book. Height $247 \mathrm{~mm}$. Acc. No. 1960-I-69B. Forming a set with 68 , 70 and 71 .

70 AFRICA. Female figure, wearing elephant-head coif, seated on reclining lion; attribute: cornucopia. Height $245 \mathrm{~mm}$. Acc. No. I960-I-69c. Forming a set with 68,69 and 71 .

71 AMERICA. Female figure with feather headdress and with quiver on back, seated on alligator, the left hand resting on a cockatoo; on the ground, a severed human head. Height $248 \mathrm{~mm}$. Acc. No. I960-I-69D. Forming a set with 68,69 and 70. Variant of Alcora porcelain 56.

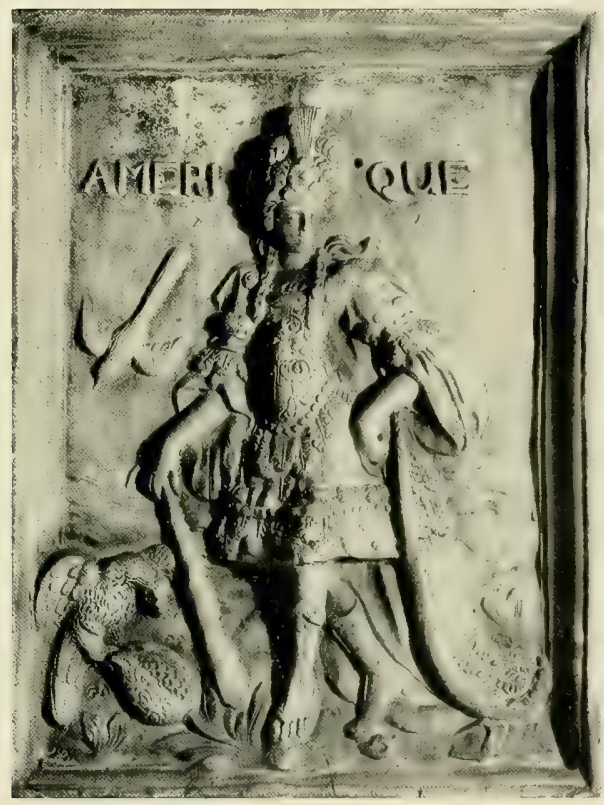

Catalogue Number 73

72 AMERICA, Stove tile. Relief: under an arch supported by columns, a female figure in feather skirt, holding shield and arrow, seated on a tortoise (or armadillo); crested with shield and two figures. Green-glazed earthenware. Austria or Switzerland, late i 7th century. Height $296 \mathrm{~mm}$. Acc. No. $1960-1-73$.

73 AMERICA (AMERIQUE); Stove tile. Relief figure in regal attire, with feather cape and aigrette, holding a club; attributes: two macaws and tropical fruit. Unglazed buff earthenware. France; I7th century. Height $369 \mathrm{~mm}$. Acc. No. I960-I-75. (Illustrated) 
TILE PANEL. Six square and three rectangular tiles, set in cement. St. Ignatius of Loyola kneeling on globe, set aflame by lightning emanating from his raised right hand; in sky, halo-encircled IHS; attended by four female figures, allegories of the Four Continents, and their animals: cockatoo, alligator, horse and camel. Inscription: ET QUID VOLO NISI UT ACCENDATUR/ACCENDETUR VELUT IGNIS ZELUS TUU. PS 70. Light buff earthenware with polychrome underglaze painting; related to an engraving by Petrus Costa (died I 761). Spain, Talavera; early I 8 th century. Height $604 \mathrm{~mm}$. Acc. No. I960-I-74.

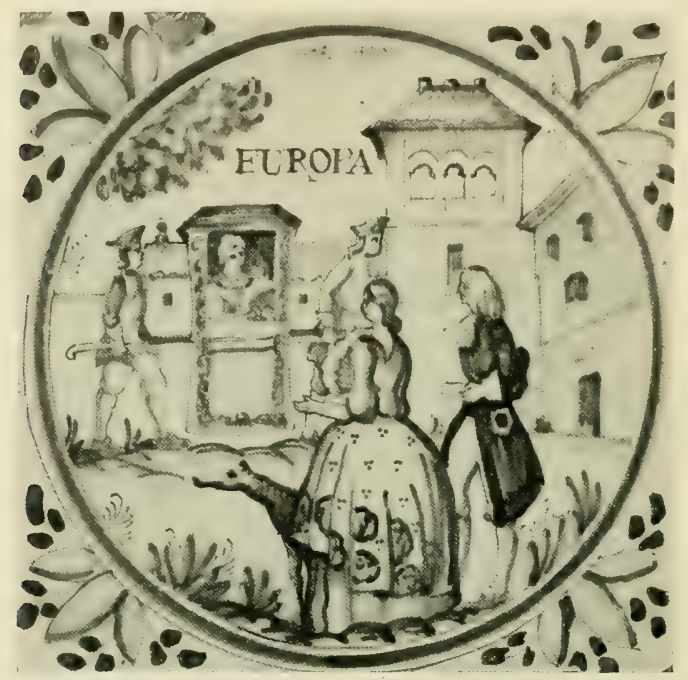

Catalogue Number 76

75 ASIA. Tile with circular medallion; turbaned figure riding in howdah on back of elephant, with two attendants; birds in foreground, turreted architecture in background. Pale buff earthenware with blue underglaze painting. Spain, I 8 th century. Height $27 \mathrm{I} \mathrm{mm.} \mathrm{Acc.} \mathrm{No.} \mathrm{I960-I-72A.} \mathrm{Forming}$ a set with 76,77 and 78 .

76 EUROPE(EUROPA). Tile with circular medallion; lady, cavalier and dog in foreground, watching a sedan chair, carried by two men; Spanish architecture in background. Height $262 \mathrm{~mm}$. Acc. No. 1960-I-72B. Forming a set with 75,77 and 78 . (Illistrated)

77 AFRICA. Tile with circular medallion; turbaned man and woman, with attendant holding parasol; attributes: monkey, ostrich and camel. Height $268 \mathrm{~mm}$. Acc. No. I960-I-72C. Forming a set with 75,76 and 78 .

78 AMERICA. Tile with circular medallion; Indian in feather skirt and headdress, carried in high seat on poles by five similarly but less ornately dressed Indians, and attended by one holding a fan; at left, a conquistador on horseback, and a cockatoo on a branch; in right background, a sailing ship. After illustration No. 37 by Jacques LeMoyne de Morgues in Brevis Narratio Eorum Quae in Florida Americae Provincia Gallis Acciderunt; engraved by Theodor de Bry (I 528-1 598); Frankfort, I 59I. Height $268 \mathrm{~mm}$. Acc. No. I960-I-72D. Forming a set with 75,76 and 77 . 


\section{DRAWINGS}

79 THE LANDING OF COLUMBUS IN THE NEW WORLD. Sketch for a lost fresco in the Sala del Consiglio of the Senatorial palace in Genoa. The irregularly-shaped composition shows at the left, Columbus, banner in hand, accompanied by his retinue, setting foot in the New World, and putting to flight two nude Indians. In the centre, in the sky, the allegory of Faith. Verso: pencil sketch of the same subject, though with changes in the composition. Drawing, pencil, pen and ink with grey wash on paper; by Francesco Solimena (I657-1747). Italy, Naples; I7I 5-I725. Height $263 \mathrm{~mm}$.; length $542 \mathrm{~mm}$. Acc. No. 1960-I-92.

8o EUROPE. Bust-length female figure, wearing a crown and holding a sceptre. Colored pastels on paper; by Rosalba Carriera(I675-I757). Italy, Venice; probably before I 720 . Height 44I 1mm.; length $342 \mathrm{~mm}$. Acc. No. I960-I-7B. Forming part of a set with 81 and 82 .

81 AFRICA. Bust-length negro female wearing a jewelled turban, pearl earrings and necklace, and holding a scorpion. Colored pastels on paper; by Rosalba Carriera (I675-I 757). Italy, Venice; probably before I 720 . Height $438 \mathrm{~mm}$. ; length $342 \mathrm{~mm}$. Acc. No. 1960-I-7C. Forming part of a set with 80 and 82 . (Illustrated)

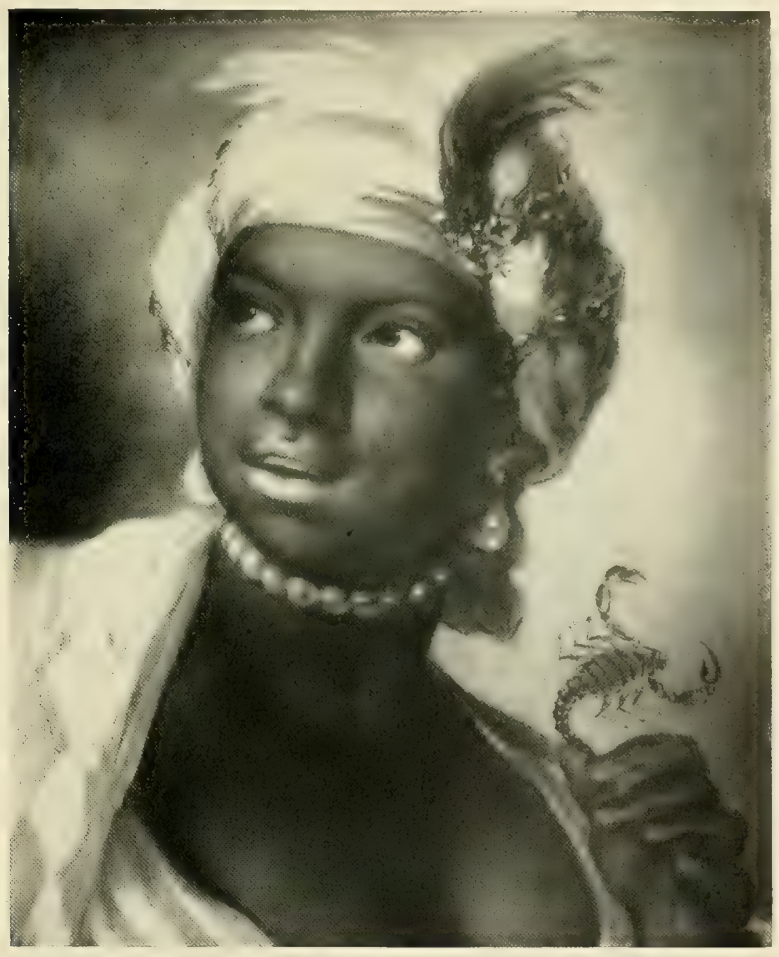

Catalogue Number 81 
AMERICA. Bust-length fenale figure of an Indian, wearing a jewelled hair fillet decorated with plumes, and carrying an arrow; on her back, a quiver filled with arrows. Colored pastels on paper; by Rosalba Carriera (I675-I757). Italy, Venice; probably before 1720 . Height $435 \mathrm{~mm}$.; length $340 \mathrm{~mm}$. Acc. No. 1960-I-7D. Forming part of a set with 80 and 81 .

\section{GLASS}

83 STANDING CUP with figures of the Four Continents: Asia with arrow and bow, attended by lion; Europe, holding cornucopia and banner with the coats of arms of the House of Habsburg and the eight Electors, seated on bull; Africa, in large flat hat, seated on crocodile; America with feather skirt and headdress, carrying arrow and coral, attended by elephant; on foot, floral scrolls. Honey-comb-cut and engraved glass. Silesia; I680-I690. Height $209 \mathrm{~mm}$. Acc. No. 1960-I-83 (Illustrated)

84 TUMBLER, with the figures of the Four Continents between scrolls and garlands: Asia (Asien), standing, holding censer; Europe (Europa) crowned, holding sceptre; Africa with tambourine and feather parasol; America, with feather skirt and headdress, holding spear and sponge(?). Engraved glass; after drawings by Abraham Bosse (I602-1676), engraved by Le Blond. Silesia, early I 8 th century. Height I $3 \mathrm{~mm}$. Acc. No. I960-I-80.

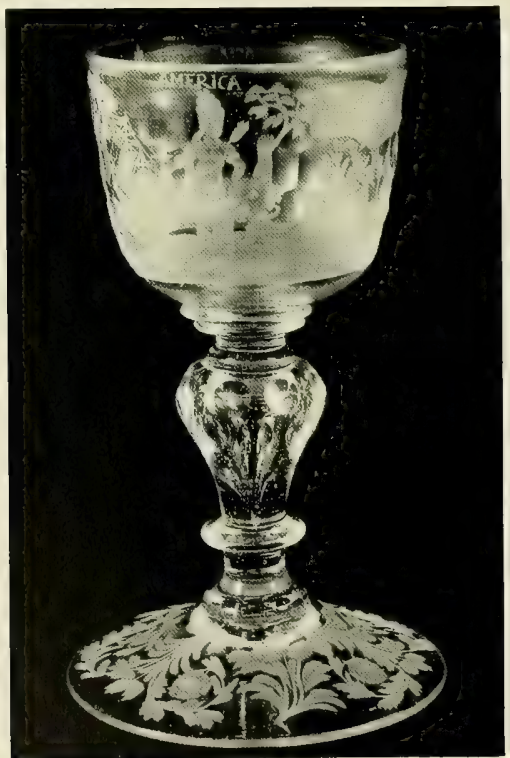

Catalogue Number 83 
STANDING CUP with the figures of the Four Continents in circular medallions between scrollwork. Asia, in Turkish costume, seated, leaning on shield, holding lamp and long sceptre; attended by camel; Europe, crowned, holding sceptre and cornucopia; attended by horse; attributes: globe, arms and armor; Africa, holding grapes, paddle and pomegranate; attended by faun, monkey, lion and elephants; America, kneeling, with feather skirt and headdress, holding arrow and bird; attended by crouching puma; in background, three kneeling figures in front of an idol. Cut and engraved glass, after the frontispiece to Thesauri Philo-Politici Tertia Pars, Frankfort, 1623 , attributed to Georg Keller(I $568-1634)$. Bohemia; first half of the I 8 th century. Height $208 \mathrm{~mm}$. Acc. No. I960-I78.

86 STANDING CUP WITH COVER, with the figures of the Four Continents between rocaille columns. Asia in Turkish costume, holding sceptre with crescent; in background, camels and Oriental town; Europe, crowned, holding orb and sceptre, with scroll and terrestrial globe at her feet; in background, a gentleman, a river with ships, and a town; Africa in feather skirt and headdress, holding arrow; attributes: monkey, elephant and palm tree; America in feather skirt, collar and headdress, holding arrow; attended by lion, crocodile and camel. Cut and engraved glass, with gold band on rim and cover, and gilded top of finial. Bohemia, r 8th century. Height, with cover, $289 \mathrm{~mm}$. Acc. No, 1960-I-8I.

87 STANDING CUP with the figures of the Four Continents between vases of flowers: Asia, with turban, reaching into basket full of gems; Europe, crowned, holding sceptre; Africa with feather headdress and sceptre, holding bird; America, with feather cape and headdress, holding bow and arrow. Diamond-cut and engraved glass. Germany, probably Hesse or Latenstein; I8th century. Height $257 \mathrm{~mm}$. Acc. No. I960-I-84.

88

STANDING CUP with medallions of two continents between scrollwork. Europe, crowned, holding sceptre and shield with Habsburg coat of arms; attributes: horse, helmet, and banners (after engraving by Johannes Meyer (I655-I7 I2), printed on a New Year's broadside, "Geographia", for 1706 issued by the Burgerliche Bibliotec, Zürich; Africa, holding tambourine and parasol, attended by buffalo and crocodile. Cut and engraved glass. Germany, Thuringia(?); r 8th century. Height $254 \mathrm{~mm}$. Acc. No. 1960-I-82.

\section{METALWORK}

\section{Silver}

89 TWO TEA CADDIES. Chased silver with chinoiserie decoration by William Cripps, following motifs used by Paul de Lamerie (1688-175I). England, London; 1752-1753. Marks: leopard's head, lion passant. W. C., date letter $r$. Height $145 \mathrm{~mm}$. and $151 \mathrm{~mm}$. Acc. No. I960-I-IA and -I B. From a set originally comprising three pieces.

9o TEA URN. Atlas supporting globe adorned with repoussé medallions of the Four Continents. Silver, by Thomas Heming, goldsmith to George II. England, London; I777-1778. Marks: leopard's head, lion passant, T. H. crowned, date letter $b$. Height $446 \mathrm{~mm}$. Acc. No. I960-I-23.

91 DISH. Oval, with four repoussé martial trophies on marli and wreath around centre. Applied, on marli, four high relief medallions with the Four Continents after Stefano della Bella's (I6IO1664) playing-cards, published in Paris in I646. Asia, turbaned, in chariot drawn by two elephants; Europe, crowned, drawn by horses; Africa, with feather headdress and parasol, drawn by lions; America, in feather headdress and tunic, drawn by armadillos. In centre, relief plaque of Alexander and King 
Darius, lying dead in battle chariot, with attending warriors; inscription: Alexander beweiint den Todt des Königs Darius; after an etching of 1656 by Hans Ulrich Frank (I603-I680). Silver on silver-gilt, by Adolf Gaap (died I695). Germany, Augsburg; 1689. Signed and dated; marks: AG and pineapple. Length $719 \mathrm{~mm}$. Acc. No. I960-I-2I. (Illustrated)

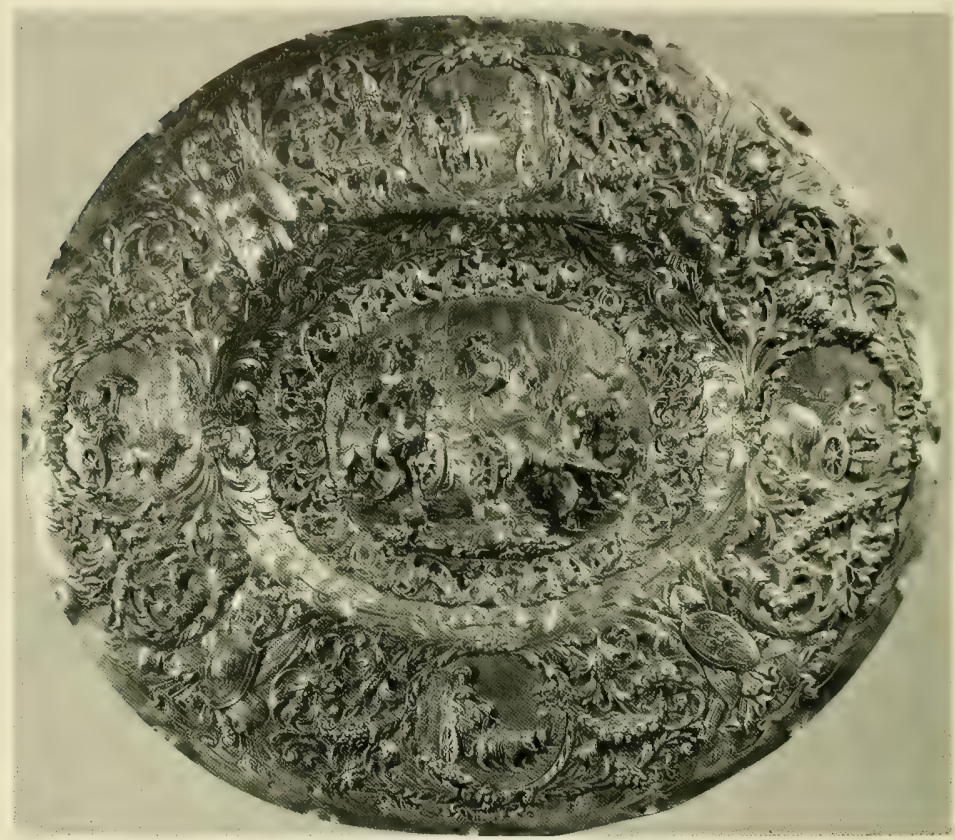

Catalogue Number 91

92 SALVER. Lobed oval, on scrolled feet, with four-lobed relief medallions of the Four Continents. Silver-gilt, engraved, by Johann Erhard Heuglin II(Master I7I7, died 1757). Germany, Augsburg; about I725. Marks: I E H and pineapple. Length $272 \mathrm{~mm}$. Acc. No. I960-I-17.

93 COVERED PORRINGER. On cover, four-lobed relief medallions of Africa and the Four Elements; on bowl, medallions of Fishing and Trapping. Silver-gilt, engraved, by Johann Erhard Heuglin II (Master 1717, died 1757). Germany, Augsburg; about I725. Marks: IE H and pineapple. Diameter I30 mm. Acc. No. I960-I-I8.

94 EWER. Helmet-shaped, with four-lobed relief medallions of Asia and America, and smaller medallions of Geometry, Music, Poetry, etc. Silver-gilt, engraved, by Nicolaus Ostertag (Warden 1721, died 174I). Germany, Augsburg; about 1730. Marks: NO and pineapple. Height $270 \mathrm{~mm}$. Acc. No. I960-I-I9A. Forming a set with 95. (Illustrated)

95 DISH. On marli, four-lobed relief medallions of the Four Continents alternating with the Four Elements; in centre, Hercules crowned by Victory. Marks: NO and pineapple. Diameter 526 mm. Acc. No. I960-I-I9B. Forming a set with 94. 
TAZZA. Scrolled base with four pairs of seated figures representing the Four Continents; arms of Solomon Rothschild (I774-I 885 ). Silver, by Charles Odiot after a design by Félix Loutis Jacques Duban(I797-1 870). France, Paris; about I 840 . Marks: vase in lozenge, bearded head, and ODIOT. A PARIS. Height $265 \mathrm{~mm}$. Acc. No. 1960-1-22.

97 GOBLET. American Indian, in feather skirt and headdress, holding up globular cup, engraved with coat of arms, two gentlemen shaking hands, and legend: Tretter Freunde Fretundschafts Pflicht Endert Sich im Grabe nicht. Silver-gilt, by Johann Jacob Adam (master 1748, died I792); cut and engraved glass. Germany, Augsburg; I75I-I753. Marks: IIA in oval, and pineapple. Height $259 \mathrm{~mm}$. Acc. No. 1960-I-20. (Illustrated)

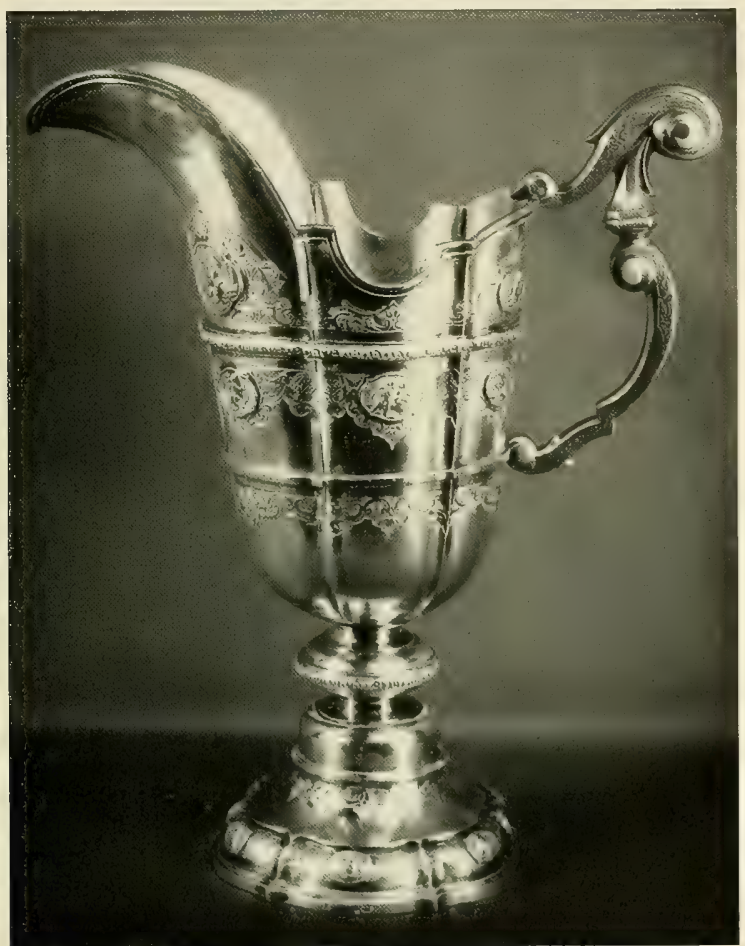

Catalogue Nimber 94

TABLE CLOCK. Terrestrial globe on stepped pedestal with figures representing the Five Continents: Asiatic woman with five-headed cobra, Europa with the Bull, African hunter with lioness, American Indian on horseback, South-Sea Islander on dolphin; twenty-four-hour equatorial dial with the signs of the zodiac. Silver, by Atelier Borgila: designed by Erik Fleming (1894-1954), modeled by Karl Hultström, works by Robert Engström. Presented by the Swedish Match Company to Ivar Kreuger (1880-1932) on his fiftieth birthday. Sweden, Stockholm; 1930. Marks: Borgila, three crowns, S, head, D8. Height $460 \mathrm{~mm}$. Acc. No. 1960-I-16. (Illustrated) 


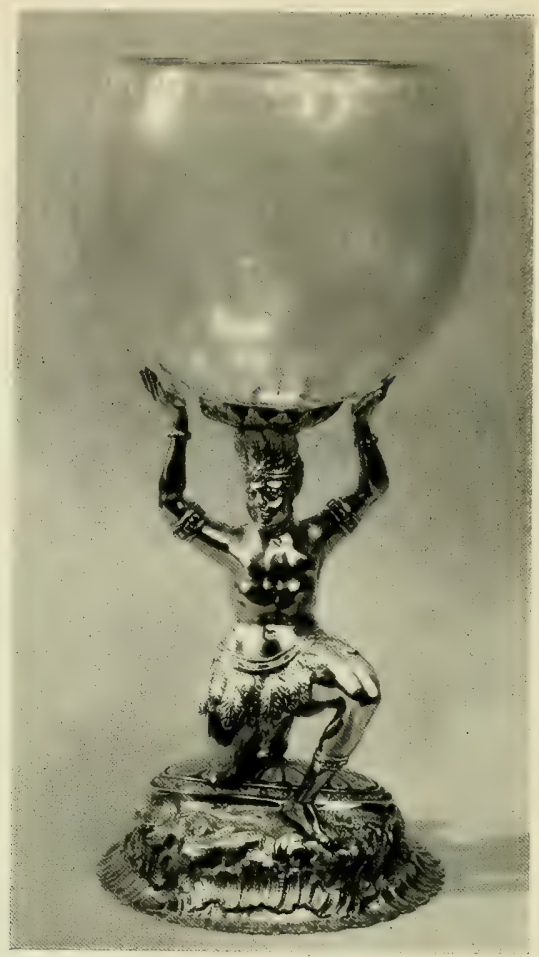

Catalogue Number 97

\section{Other Metals}

99

ASIA. Relief plaque with arched top; seated female figure holding branch of laurel and censer; a camel at her right. Bronze; probably intended as inset in cabinet front. France, I7th century. Height 2 I I mm. Acc. No. 1960-I-9A. Forming a set with 100, 101 and 102.

100 EUROPE. Relief plaque with arched top; seated female figure, wearing ermine and crown, holding sceptre and cornucopia; at her right, horse, tempietto, papal crown, dish and ewer; at her feet, sculpture head, books, palette and brushes. Acc. No. 1960-I-9B. Forming a set with 99, 101 and 102.

101 AFRICA. Relief plaque with arched top; female figure seated in left profile on lion; holding scorpion and cornucopia. Acc. No. I960-I-9C. Forming a set with 99, 100 and 102.

102 AMERICA. Relief plaque with arched top; female figure at right profile, with feather headdress and skirt; holding bow and quiver in left and parrot on right hand, and stepping on alligator's head. Acc. No. 1960-I-9D. Forming a set with 99, 100 and 101.

103 AMERICA. Female figure dressed in feather skirt, cloak and headdress, seated on iguana; in her right hand, a spear. Copper-gilt, repoussé; perhaps intended as inset in cabinet front. Germany, second half of the I 7 th century. Height I $54 \mathrm{~mm}$. Acc. No. I960-I-9I. 
ENGRAVED PLATE. Bust portrait of Vasco Nuñez de Balboa ( $1475-1517$ ), framed by intertwining snakes and flanked by American Indian man and woman with child, a llama, puma and monkeys among trees. Brass; probably used for the printing of a title page. Germany, Franconia; 17 th century (?). Height I $87 \mathrm{~mm}$. Acc. No. I960-I-IO.

105 POCKET SUN DIAL AND COMPASS. Scrolled square frame with animal allegories of the Four Continents: camel, horse, lion and monkey; hinged quadrant, hour circle with gnomon and pendulum; in centre, recessed circular box with compass needle, the face engraved with mermaid and triton; set on three adjustable legs. Gilt brass and steel. Germany, Augsburg; about I710. Marked: J.E.L. Augspurg. 48 G Gr. 60 x 65 mm. Acc. No. 1960-I-I2. (Illistrated)

106 EMBLEM OF EUROPE. Applique; panoplied cartouche with rearing horse. Gilt bronze. France, third quarter of the I 8 th century. Height $80 \mathrm{~mm}$. Acc. No. I960-I2I-I.

107 EUROPE. Applique; female figure wearing helmet and holding a sceptre and cornucopia, seated on reclining horse. Unfinished bronze. France, I 8 I 5-1830. Height 9I mm. Acc. No. I960-12 I4. Part of a set with 108 and 109 .

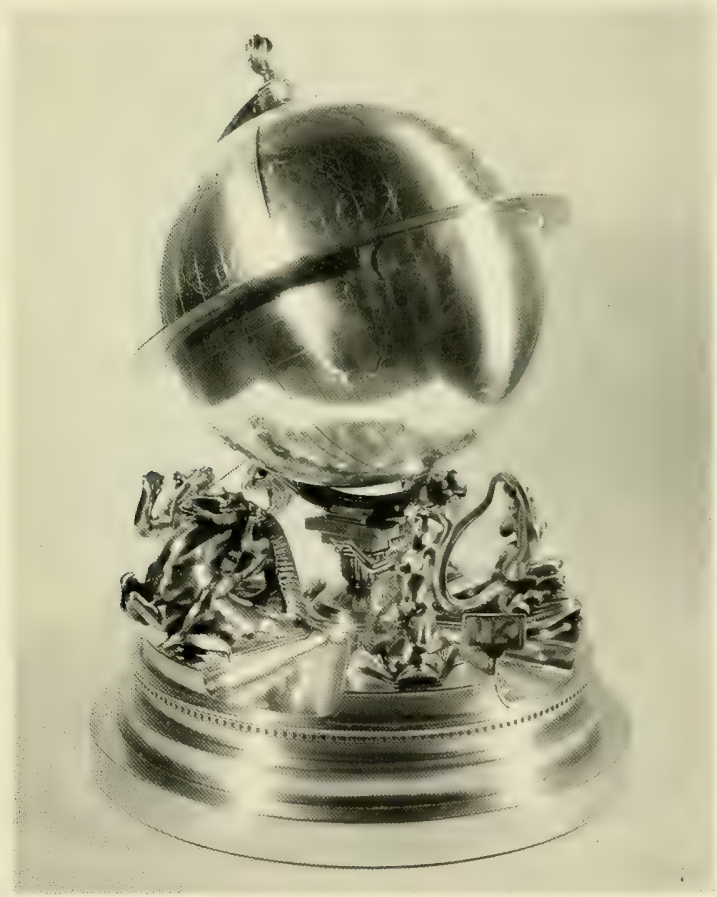

Catalogue Number 98 


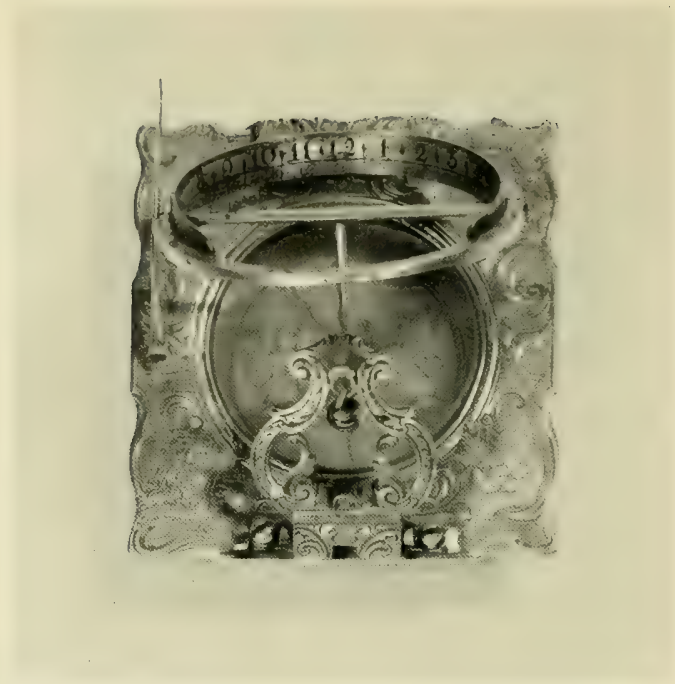

Catalogue Number 105

108 AFRICA. Applique; female figure holding cornucopia and scorpion, seated on lion. Gilt bronze. France, I8I 5-I 830. Height $88 \mathrm{~mm}$. Acc. No. I960-I2 I-3A. Part of a set with 107 and 109.

109 AMERICA. Applique; female figure in feathered skirt and headdress, holding bow and arrow, seated on tortoise. Gilt bronze. France I8I 5-1830. Height $92 \mathrm{~mm}$. Acc. No. I960-12I-3B. Part of a set with 107 and 108 .

110 AMERICA. Applique; female figure holding bow and crossbow, seated on tortoise. Bronze, partly blackened. France, I8I 5-1830. Height 84 mm. Acc. No. 1960-14I-2.

\section{TEXTILES}

111 TAPESTRY, oval detail; ASIA, a seated man, wearing a turban and loose robe, carries a sceptre and rests his arm on a bale, on which lies a crowned turban; at his feet a scimitar; at back appear heads of camels. Wool in shades of red, blue, brown and cream. Netherlands, late I 7 th century. Probably a detail from a table-cover. IM290 by $870 \mathrm{~mm}$. Acc. No. I960-I-I4A. Forming a set with 112, 113 and 114 .

112 TAPESTRY, oval detail; EUROPE, seated female, crowned and with sceptre; beside her a rearing horse. IM3 I 5 by $870 \mathrm{~mm}$. Acc. No. I960-I-I 4B. Forming a set with 111,113 and 114 . 
113 TAPESTRY, oval detail; AFRICA, a seated female, in light robe and broad-brimmed hat, carries a spear; at her feet a bow and quiver of arrows; beside her an elephant. IM 3 I o by $870 \mathrm{~mm}$. Acc. No. I960-I-I4C. Forming a set with 111,112 and 114 .

114 TAPESTRY, oval detail; AMERICA, a seated Indian in low feathered headdress and skirt, carries a parrot on his right hand, and holds an arrow in his left. A puma lies at his feet. Enframement of drapery and volutes, with entwined branches. IM3 Io by $860 \mathrm{~mm}$. Acc. No. I960-I-I 4D. Forming a set with 111,112 and 113 .

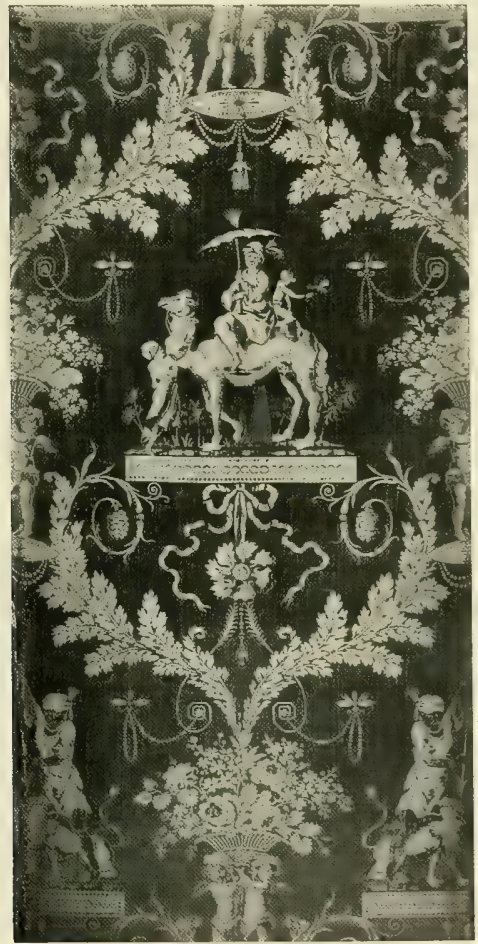

Catalogue Number 115

115 PANEL of silk, with design of allegorical figures representing the Four Continents. ASIA, a man seated on a camel, carrying an open parasol; behind him an ape, playing with a butterfly. EUROPE, a seated female, helmeted, rests her hand on a shield, on which appears a horse; attributes: flags, trumpet, anchor, caduceus, cornucopia. AFR ICA, men wearing plumed turbans spearing lions. AMERICA, seated Indians, in high feathered headdress, carrying a bow and playing with parrot on knee. Damask weave in pale yellow silk; after designs by Joseph Bourne and Pascal Picart. France, Lyon; late I 8th century. Height $2 \mathrm{MI} 60$, Width $530 \mathrm{~mm}$. Acc. No. I960-I-89. (Detail illustrated) 


\section{VARIOUS}

ASIA (L'ASSIE). Game-counter box, rectangular, with hinged cover: female figure holding censer and turban, seated in camel-drawn chariot, with attendant in background. Inside, game counters. Ivory, polychrome on rose ground, engraved; after a drawing by Martin de Vos ( $1532-$ I603), engraved by Julius Goltzius. France, late I7th century. Length $85 \mathrm{~mm}$. Acc. No. I960-I-I3A. Forming a set with 117,118 and 119 .

117 EUROPE(L'EUROPE). Game-counter box, rectangular, with hinged cover; female figure, crowned, holding sceptre and orb, seated in horse-drawn chariot. Inside, game counters. Ivory, polychrome on white, engraved. Length $83 \mathrm{~mm}$. Acc. No. 1960-I-I3B. Forming a set with $116,118 \mathrm{n}$, and 119 .

118 AFRICA(L'A FRIQUE). Game-counter box, rectangular, with hinged cover; female figure, holding parasol and tambourine, seated in lion-drawn chariot. Inside, game counters. Ivory, polychrome on yellow ground, engraved. Length $84 \mathrm{~mm}$. Acc. No. 1960-I-I3C. Forming a set with 116, 117 and 119 .

119 AMERICA (LAMERIQUE). Game-counter box, rectangular, with hinged cover; female figure in feather skirt and headdress, carrying bow, quiver and tomahawk, seated in unicorn-drawn chariot. Inside, game counters. Ivory, polychrome on maroon ground, engraved. Length $84 \mathrm{~mm}$. Acc. No. I960-I-I3D. Forming a set with 116,117 and 118 .

120 SNUFF BOX. On cover, in relief, female figure representing Asia, with high headdress and censer, seated on camel; in background, lions, elephant and camel in landscape; sides of box diapered, with cartouche in front. Ivory, with silver-gilt thumb rest and hinge by C. C. France, 18 th century; after a drawing by Martin de Vos(I532-1603). Length $74 \mathrm{~mm}$. Acc. No. I960-I-26.

121 FAN, with scene showing project of a canal through Nicaragua, and figures allegorical of the Four Parts of the World. Centre, map of Central America with proposed canal and Lake of Nicaragua. Left, Mercury, God of Commerce, indicates to group of allegorical figures the passage to the Pacific. Right, the King of Spain regards the figure of Fame who holds above him the crown of immortality which will be his upon opening the passage which would lead to the welfare of all nations. Reverse, map of North and Central America and explanation. Paper, engraved and colored. Mounted on ivory incised in silver. France, I9th century. Length $270 \mathrm{~mm}$. Acc. No. I960-I-87.

122 FAN, with figures allegorical of American Independence. Centre, a group of men sawing off horns of a cow, representing England, while others milk her. Left, a man with his foot on the British lion, further left two men in attitudes of dismay, beside them a parcel marked, TEE. Right of centre, France and America embrace, and beyond a group of mourning women, representing nations of Europe, display a legend "Epoque fatale, 4 juillet I776-le I 3 mai I778." Reverse, legend giving explanation of scenes. Paper, design in colored lithography. Bone mount. France, late I 8 th century. Length $280 \mathrm{~mm}$. Acc. No. I960-I-86.

123 FAN, with figures allegorical of America and France. Centre, Minerva receives from Louis XVI the crown of peace while with her left hand she extinguishes the torch of war. Left, an Indian carries a trident and Liberty bonnet, and holds in his right hand a card with the words, Etats Unis. Right, an amour and Indian child plant a May Tree with banner bearing the words, Vive la Paix. Legend at right explains the scene. Paper, painted in polychrome and printed. France, late $r 8$ th century. Length $280 \mathrm{~mm}$. Acc. No. I960-I-85.

124 OSTRICH EGG. Carved with oval cartouches with allegories of the Four Continents: Asia, turbaned, holding sun disk, with elephant in background; Europe, helmeted, holding shield and lance, with trumpet, drum, cannon and banner as attributes; Africa, holding parasol, with two lions; 
America, with feather headdress, holding arrows, with palm tree and alligator in background; after engraving by Johannes Meyer (1655-1712), printed on a New Year's broadside, "Geographia," for I 706 issued by the Burgerliche Bibliothec, Zürich; on the pointed end, a quatrefoil and acanthus wreath. Germany, Franconia; i7th century. Height I 57 mm. Acc. No. 1960-1-27. (Illustrated)

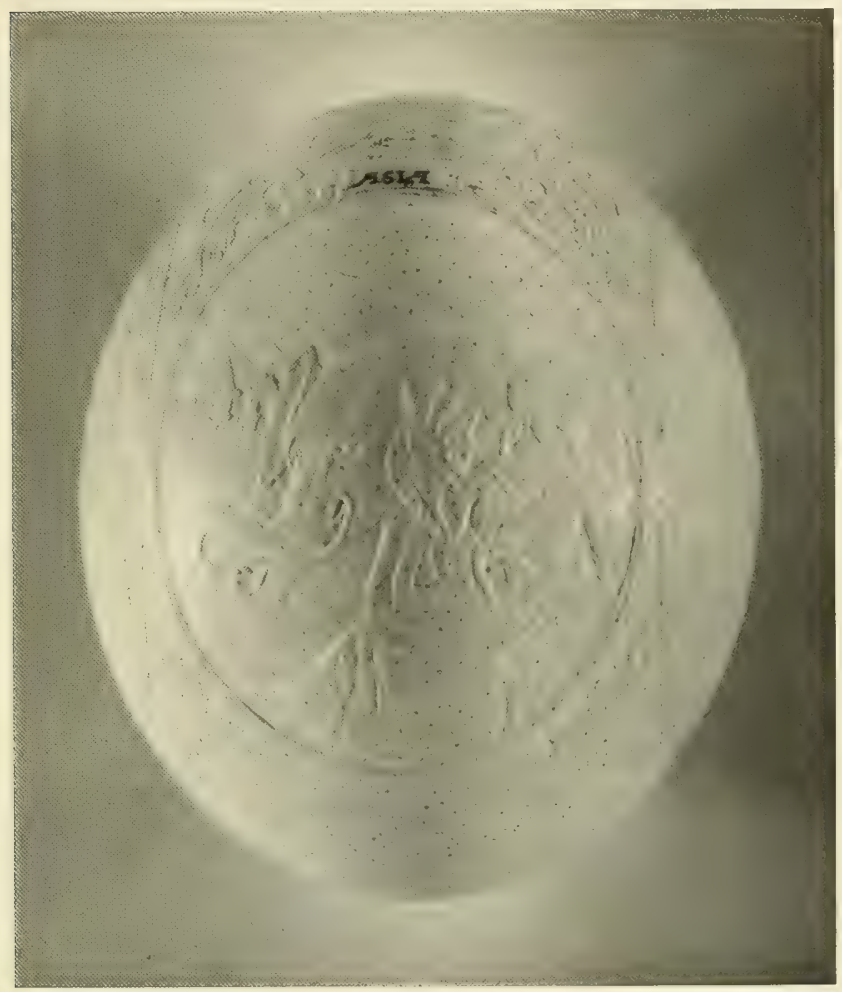

Catalogue Number 124

125 STANDING CUP WITH COVER. Tapering cup carved with the figures of the Four Continents: Asia with turban and crescent sceptre; Africa with ostrich-feather headdress and parasol; Europe with imperial crown, orb and sceptre; America with feather headdress and cape, and sceptre; stem with two putti; foot with elephant and rhinoceros interlocked in battle, and eagle; domed cover with six putti in relief and one, standing, as finial. Rhinoceros horn, mounted in silver-gilt. Germany, probably Franconia; I7th century. Total height $504 \mathrm{~mm}$. Acc. No. I960-I-25.

126 ASIA. Panel in gadrooned frame. Female figure, swinging censer, seated in chariot drawn by two camels; in background, an army beleaguering a hill town. Carved and inlaid wood (Egerverk), after a drawing by Martin de Vos (I532-1603), engraved by Julius Goltzius. Bohemia, late 17th or early I 8th century. Height $465 \mathrm{~mm}$. Acc. No. 1960-I-1 5A. Forming a set with 127,128 and 129. 
EUROPE. Panel in gadrooned frame. Crowned femalc figure, holding sceptre and orb, scated under laurel wreath in chariot, drawn by a pair of horses; in background, grazing cattle and a burning castle. Height $466 \mathrm{~mm}$. Acc. No. 1960-I-I SB. Forming a set with 126, 128 and 129 .

128 AFRICA. Panclin gadrooned frame. Nude female figure, holding tambourine and feather parasol, seated in chariot with crocodile arm rests, drawn by two lions; in foreground, scaly quadruped; in background, two elephants, camel, lion and ostrich. Height $465 \mathrm{~mm}$. Acc. No. I960-I-I SC. Forming a set with 126,127 and 129 .

129 AMERICA. Panel in gadrooned frame. Semi-nude female figure with feather headdress, holding bow and sceptre, seated in chariot drawn by two unicorns; in foreground, an armadillo; in background, men with bows inside and outside a circular enclosure. Height $466 \mathrm{~mm}$. Acc. No. I960I-I 5D. Forming a set with 126,127 and 128 .

130 FAN, with female figures allegorical of the Four Continents. On the face, centre, the equestrian statue of Joseph I of Portugal, by Joachim Machado de Castro, erected in Lisbon, I775. Left and right, seated females, clad in flowing skirt and scarf, direct attention to the statue; left, Europa with a white horse, right, America with an alligator. Reverse, the statue being raised by a crane, assisted by attendant putti; above, an inscription: "Suspendida em 20 de Mavo de 1775 ." At side, held by putti, another inscription: "Fundida em I 5 de outubro de 177 . . Coioca da em 26 de mavo de I 775 ." (Cast the Isth of October, I 77 . . Erected the 26 th of May, I775.) Left, a dark-skinned female figure, Africa, in short skirt leans against a lion; right, a female in full skirt and scarf is seated beside a camel. Paper, painted. Mounted on ivory with silver inlay. Portuguese India, late I 8th century. Length oM240. Acc. No. $1960-1-88$. 
Printed by Clarke \& Way, Inc. at The Thistle Press, New York 




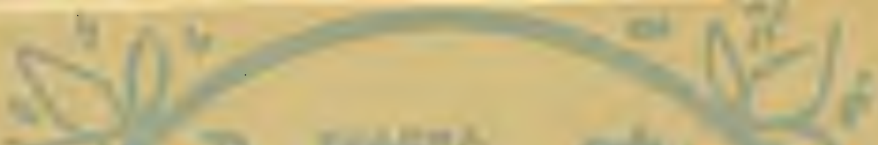

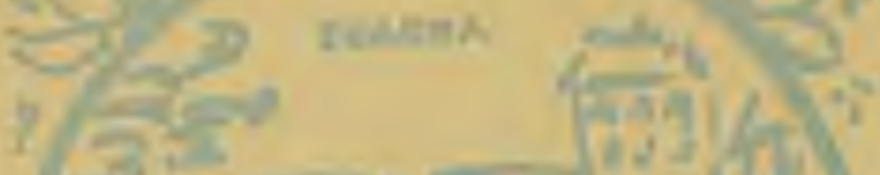

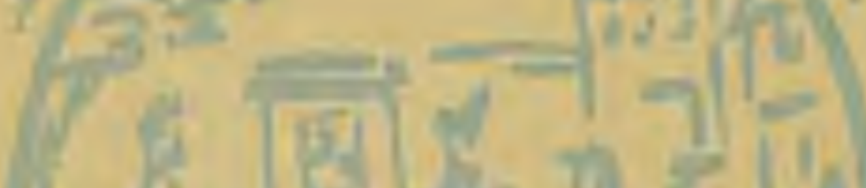

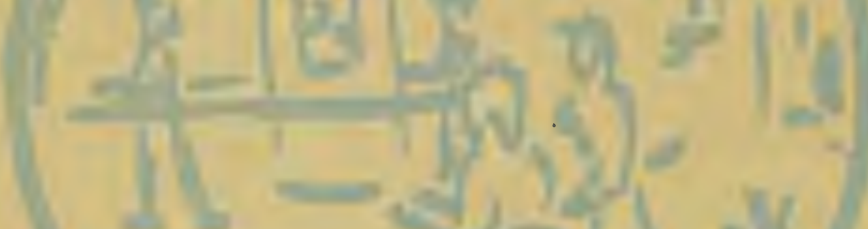

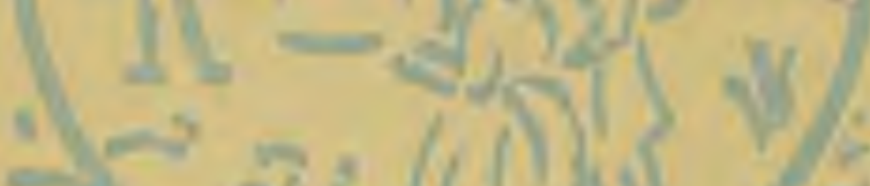

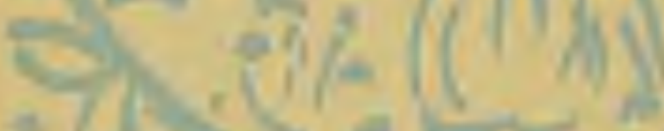
H.

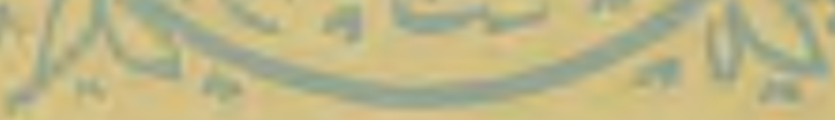

THE LOORER GuiEn FuseuM

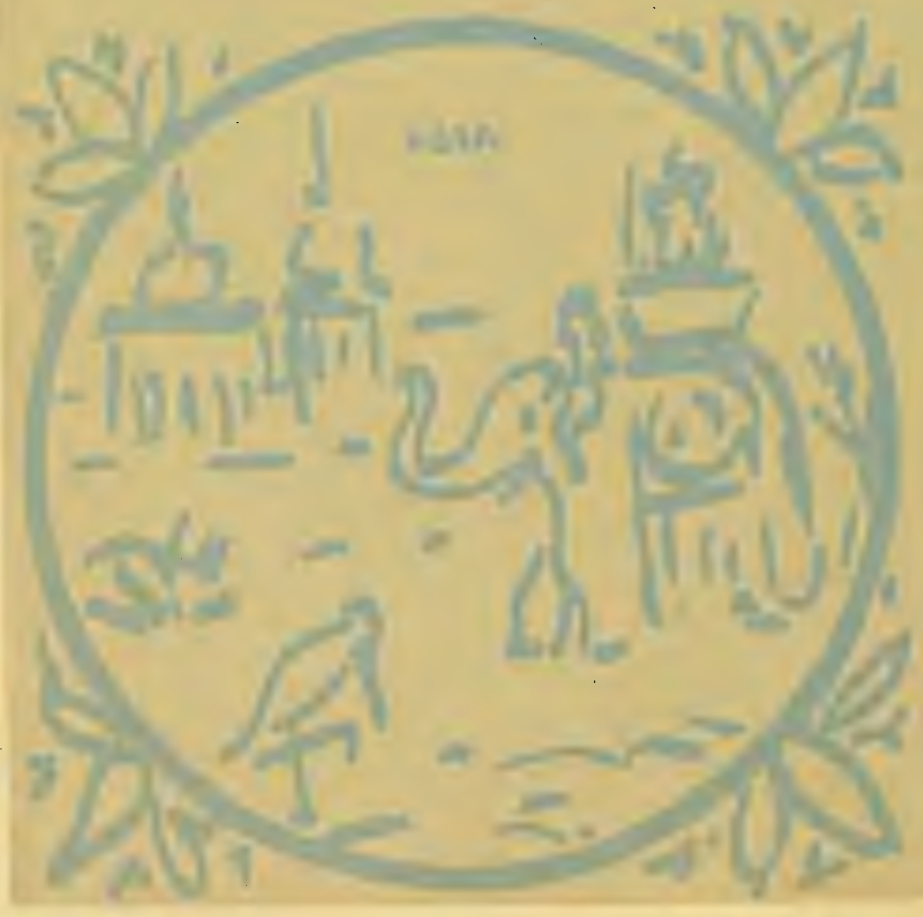





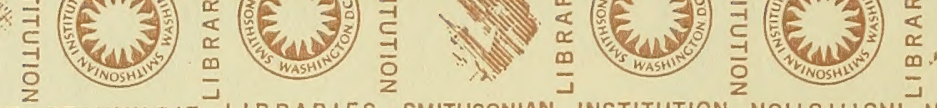

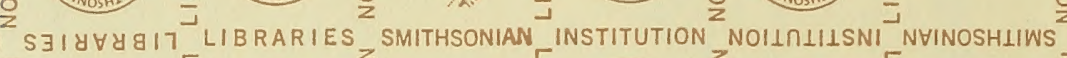
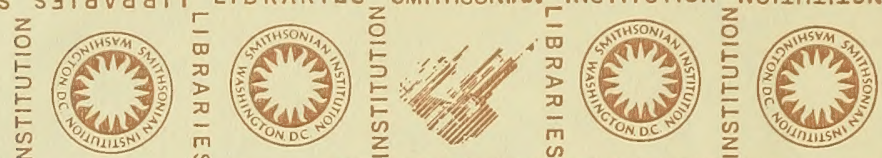

-

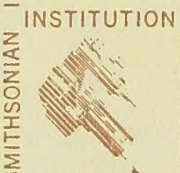

NOILIIILSNI
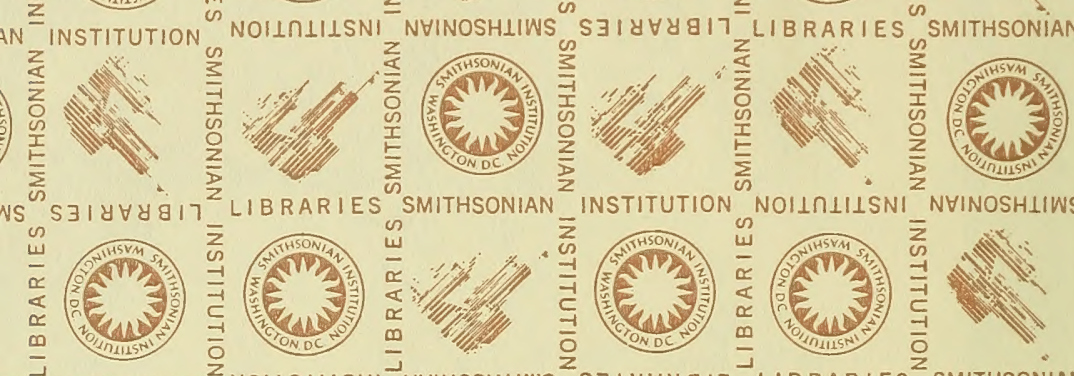

NHINOSHIIWS

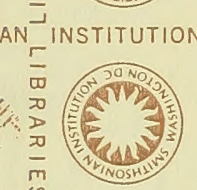

(2)
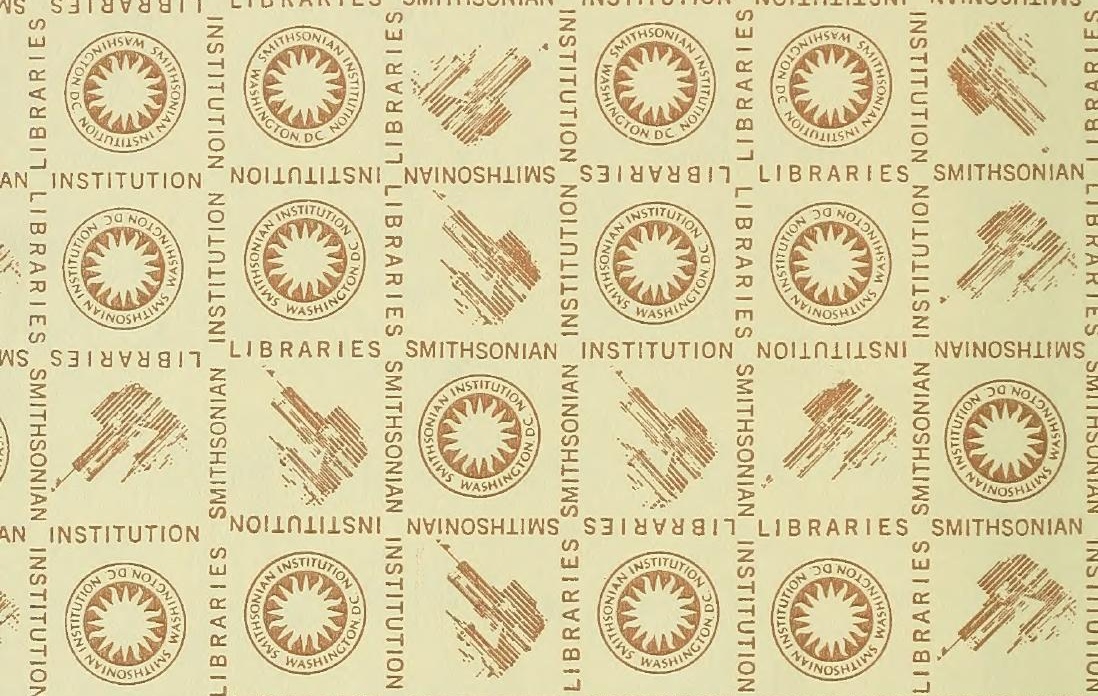

SMITHSONIAN

NVINOSHIIWS
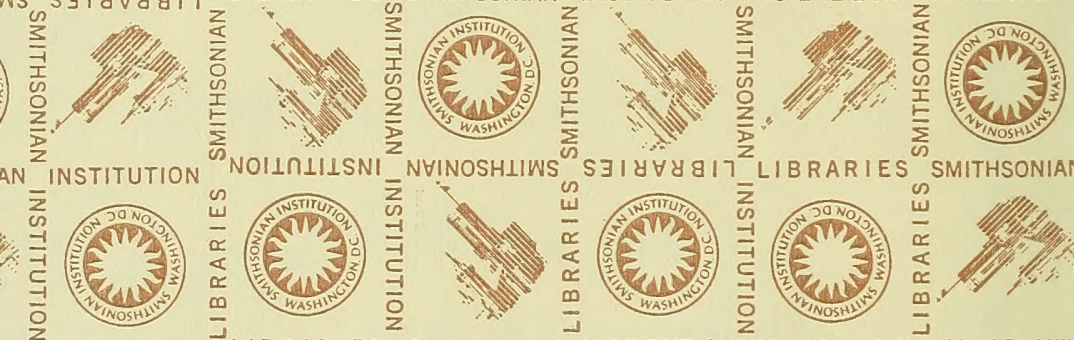

SMITHSONIAN

SS SIIYYYGII LIBRARIES
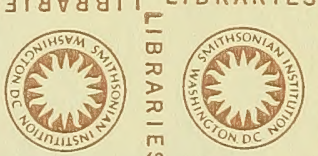

SMITHSONIAN
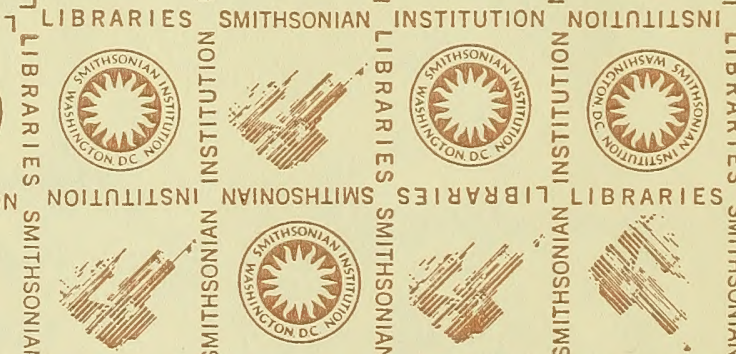

SMITHSONIAN
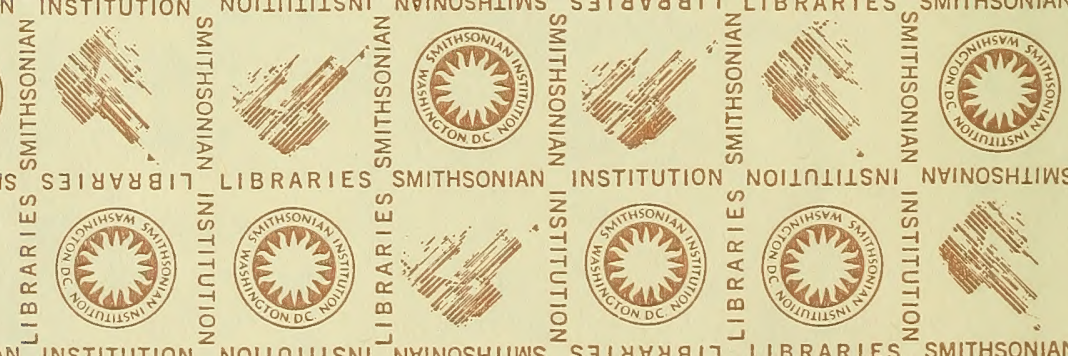

NVINOSHIIWS
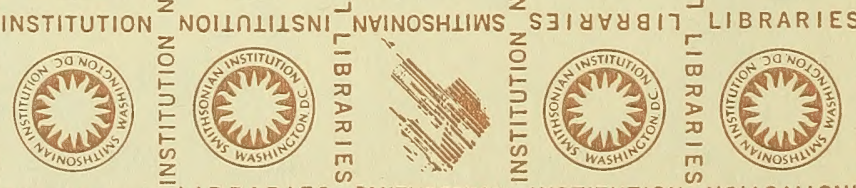

SMITHSONIAN

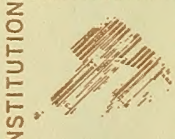

SMITHSONIAN

INSTITUTION NOILNIIISNI $z^{-}$NVINOSHIIWS 
SMITHSONIAN INSTITUTION LIBRARIES 